\title{
12 \\ Phase 2: Mounded Cultivation During the Mid Holocene
}

Tim Denham, Jack Golson and Philip Hughes

\section{Introduction}

For Golson and Hughes, the evidence of landuse 10,000 years ago at Kuk qualifies as agriculture, but for Denham it is insufficient to support this claim. In contrast, the appearance of mounded cultivation dating within the period 6950-6440 years ago at Kuk Swamp represents the earliest unequivocal evidence of agriculture in the highlands of New Guinea (Hope and Golson 1995: 823). Directly comparable, but later, mid Holocene remains have been documented at two other sites in the upper Wahgi Valley, Mugumamp and Warrawau, while more uncertain evidence has been documented at the more distant sites, Kana and Ruti (see Fig. 12.1). Evidence for early Phase 2 at Kuk and other sites in the highlands is central to arguments for the early and independent origins of agriculture in New Guinea (Hope and Golson 1995; Denham et al. 2003; Denham, Golson and Hughes 2004). In this chapter, archaeological remains at Kuk are considered in greater depth, because they have been investigated in greater detail and have guided the interpretation of finds at other highland sites.
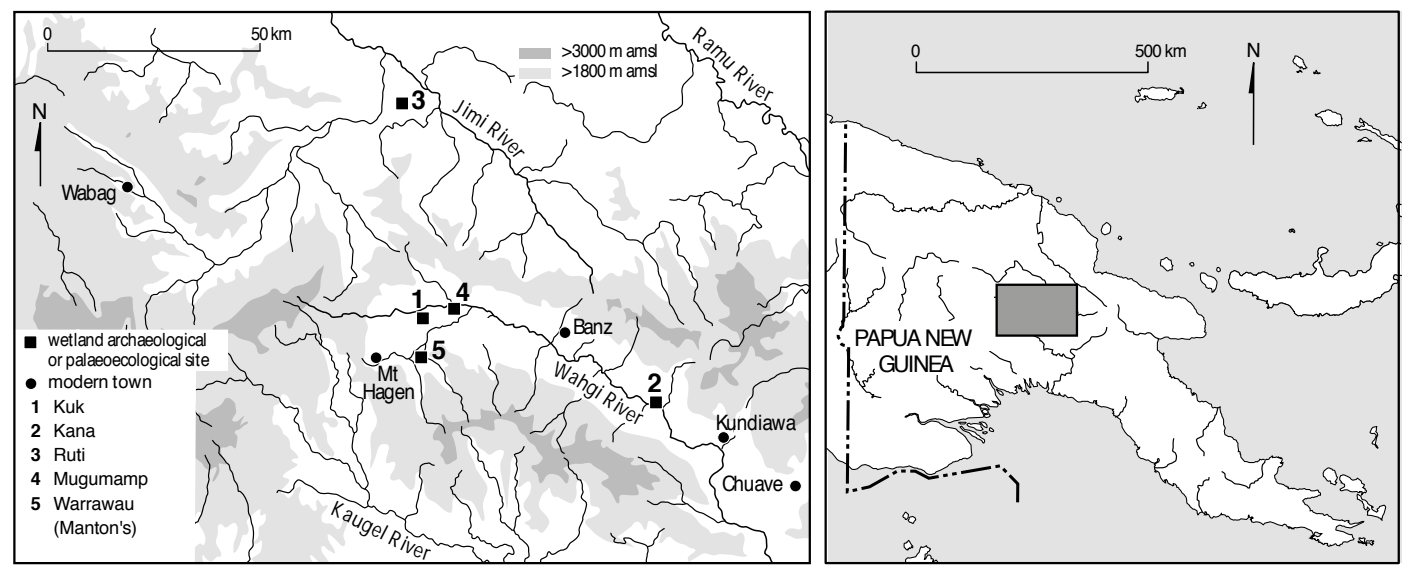

Figure 12.1 The location of sites said to have evidence comparable to Phase 2 at Kuk.

Source: Drawing by Kara Rasmanis. 


\section{Kuk}

In stratigraphic terms, Phase 2 features at Kuk postdate grey clay and predate Kim tephra (R) deposition (see Fig. 6.10). During the first years of investigation (1972-74), these features, appearing in plantation drain walls as shallow depressions in the upper surface of grey clay, were thought to be natural. Excavations undertaken in 1975 indicated they were of human origin. At least two distinct periods, or subphases, are present at Kuk: an early subphase within the period 6950-6440 years ago and a late subphase falling before 3980-3630 years ago. Both identifiable subphases are associated with distinctive and well-dated stratigraphic markers. Many early subphase features contain basal lenses of a deposit now called Red and White $(\mathrm{R}+\mathrm{W})$, which was initially thought to be a tephra and given the name Komun, but which micromorphological research has shown to be comprised predominantly of phytoliths (Denham 2003a: E4.8 and Fig. E4.8; see Table 7.1 here). $\mathrm{R}+\mathrm{W}$ dates to $6440-5990$ years ago (Table 7.2) and features that contain this deposit must predate its formation. Samples of charcoal from the basal fills of several early subphase features date to 6950-6440 years ago (Denham et al. 2003). Late subphase features contain and predate lenses of Kim (R) ash, a tephra that fell 3980-3630 years ago (Denham et al. 2003; Coulter et al. 2009; see Table 7.2 here). Some features in both subphases have neither $\mathrm{R}+\mathrm{W}$ nor $\mathrm{R}$ lenses preserved in their fill, which suggests erosion or reworking by later human activities and by soil formation.

The early subphase is better defined than the later one and is discussed in detail, whereas the late subphase is only briefly summarised because it has been poorly characterised in excavations to date. More localised subphases may be present, but have not been identified because they lack distinctive stratigraphic markers. These subphases could potentially represent spatially variable use of the wetland margin at different times in the past.

\section{Early subphase: Mounded cultivation at 6950-6440 years ago}

The archaeological and palaeoecological evidence for early Phase 2 at Kuk demonstrates prehistoric cultivation using mounds and the creation of anthropogenic grasslands at Kuk at some stage between 6950 and 6440 years ago. The early subphase has two main archaeological components: at least three palaeochannels and a palaeosurface of variable form.

\section{Palaeochannels}

Based on radiocarbon dates and diagnostic stratigraphy, three palaeochannels-William's Baret (104), Kupalg's Baret (105) and Mek's Baret (109)—are potentially contemporary with the early Phase 2 palaeosurface (Fig. 12.2). Like all but one of the palaeochannels associated with Phases 1-6, channels 104 and 105 drained the southern catchment of Kuk Swamp, whereas the exception, channel 109, located in an area of hillocks at the western end of E-W Road 3, appeared to have a very small catchment of a few hectares on the margin of the swamp.

These palaeochannels have previously been interpreted to be artificial (Golson 1977a: 615-616; Golson and Hughes 1980: 298), although a recent reassessment of the archaeological evidence questions this interpretation (Denham 2003a: 160-176; 2003b: 163-164). The slightly sinuous plans, cross-sectional morphologies and course gradients provide information that can be used to support both positions. Debate continues on this matter and the key points of dispute are summarised below.

a. Several reaches of channels 104 and 105 are relatively straight and this observation is taken by Hughes and Golson to indicate artificial construction (Figs 12.2 and 12.3). Although unusual, natural watercourses do occasionally have straight sections (Ferguson 1981: 119). Other reaches of palaeochannel course are slightly sinuous, and these are more consistent with natural watercourses. The surface traces of originally straight channels, once abandoned 
and largely filled in, can become slightly sinuous with continued flow, as happened to the undoubtedly artificial Phase 5 and 6 palaeochannels, as depicted in Winifred Mumford's 1972 map of the course of Wai's Baret (Golson 1976: Fig. 3; see Fig. 15.3 here).

b. Channels 104 and 109 have wide and shallow cross-sections, whereas that for channel 105 is deeper and U- to V-shaped (Fig. 12.4a-c). The cross-sections of the first two channels may indicate low energy flow with banks subject to subaerial erosion, whereas the cross-section of channel 105 suggests bank profiles dominated by fluvial processes and down-cutting as a result of channel rejuvenation (see Fig. 12.4c). Channel cross-sections are within the range of natural watercourses such as brooks and streams (Knighton 1998: Table 5.1).

c. Field observations made by Golson and Hughes suggested that channels 104 and 105 traversed undulating topography without deviation. In particular, channel 105 was interpreted to traverse slightly higher ground comprised of Pleistocene tephra-mantled lahar deposits, which were over $1 \mathrm{~m}$ high in the present-day landscape. As had been the case with Kundil's Baret (channel 101) of Phase 1, the straight course and passage through higher ground was interpreted as inconsistent with a natural watercourse and suggestive of artificial construction (Fig. 12.5). Despite the massive and spectacular section of channel 105 cutting through Pleistocene deposits (Fig. 12.6), it is unclear whether the higher ground existed at the time of palaeochannel formation or whether it was a product of differential shrinkage of the stratigraphy (Denham, Golson and Hughes 2004: 269-274). Unfortunately, there are no sufficiently detailed survey records for the potentially significant straight reach of channel 105 (indicated in Fig. 12.3). Channel 109 is in a different setting and its course has not been surveyed across the landscape.

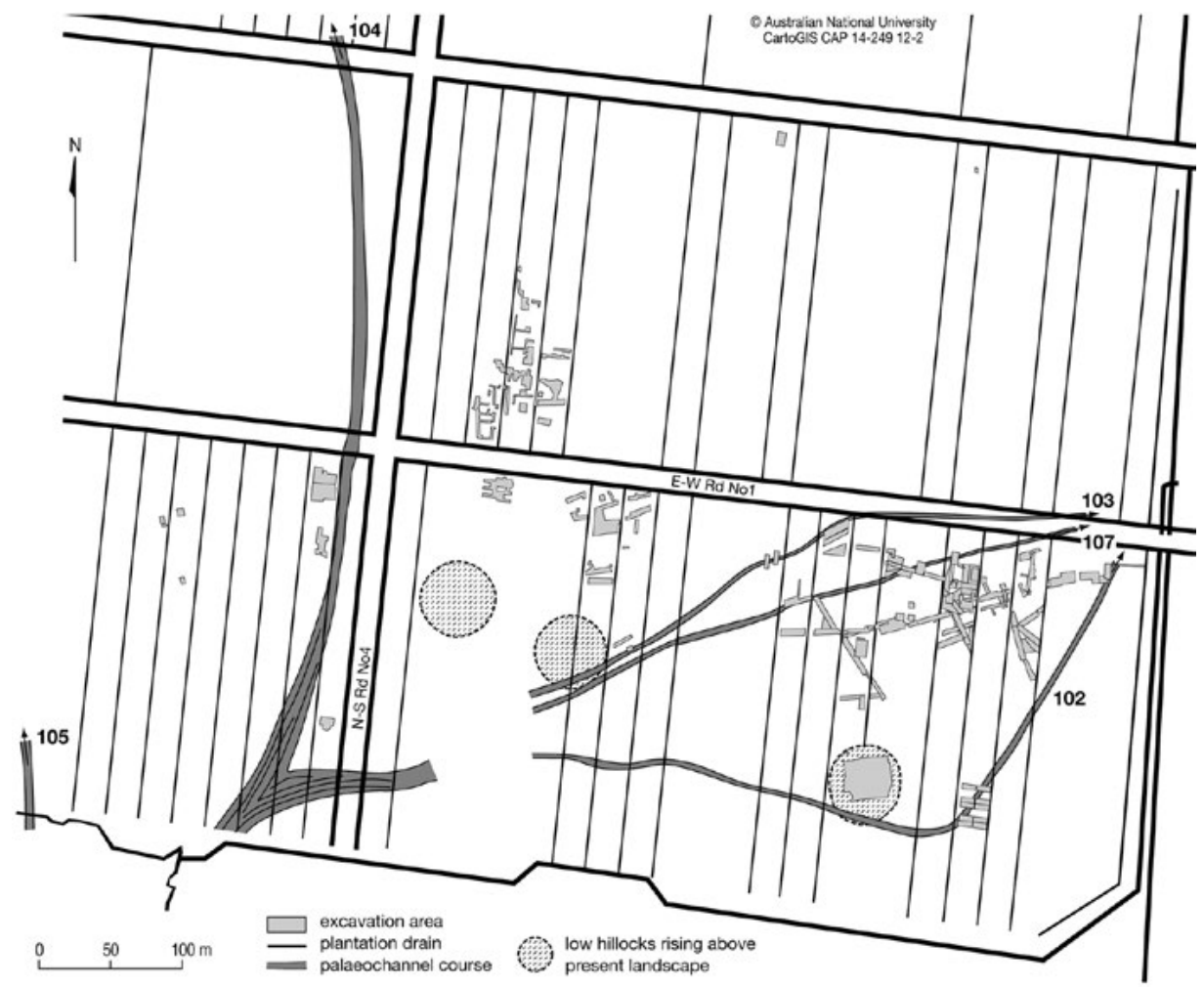

Figure 12.2 The courses of Phase 2 palaeochannels in the eastern part of Kuk Station.

Channel 105 disappears northwestwards off the map from its SW corner, while the channel at complex 109, which was the subject of only limited investigation at the northern end of block ${ }^{2}$, is off the map altogether. Only the most relevant of the low hillocks that form prominent features of the relatively flat wetland margin are shown.

Source: Denham, Golson and Hughes (2004: Fig. 11), reproduced with permission. Drawing by Jennifer Sheehan, CartoGIS Services, College of Asia and the Pacific, ANU. 

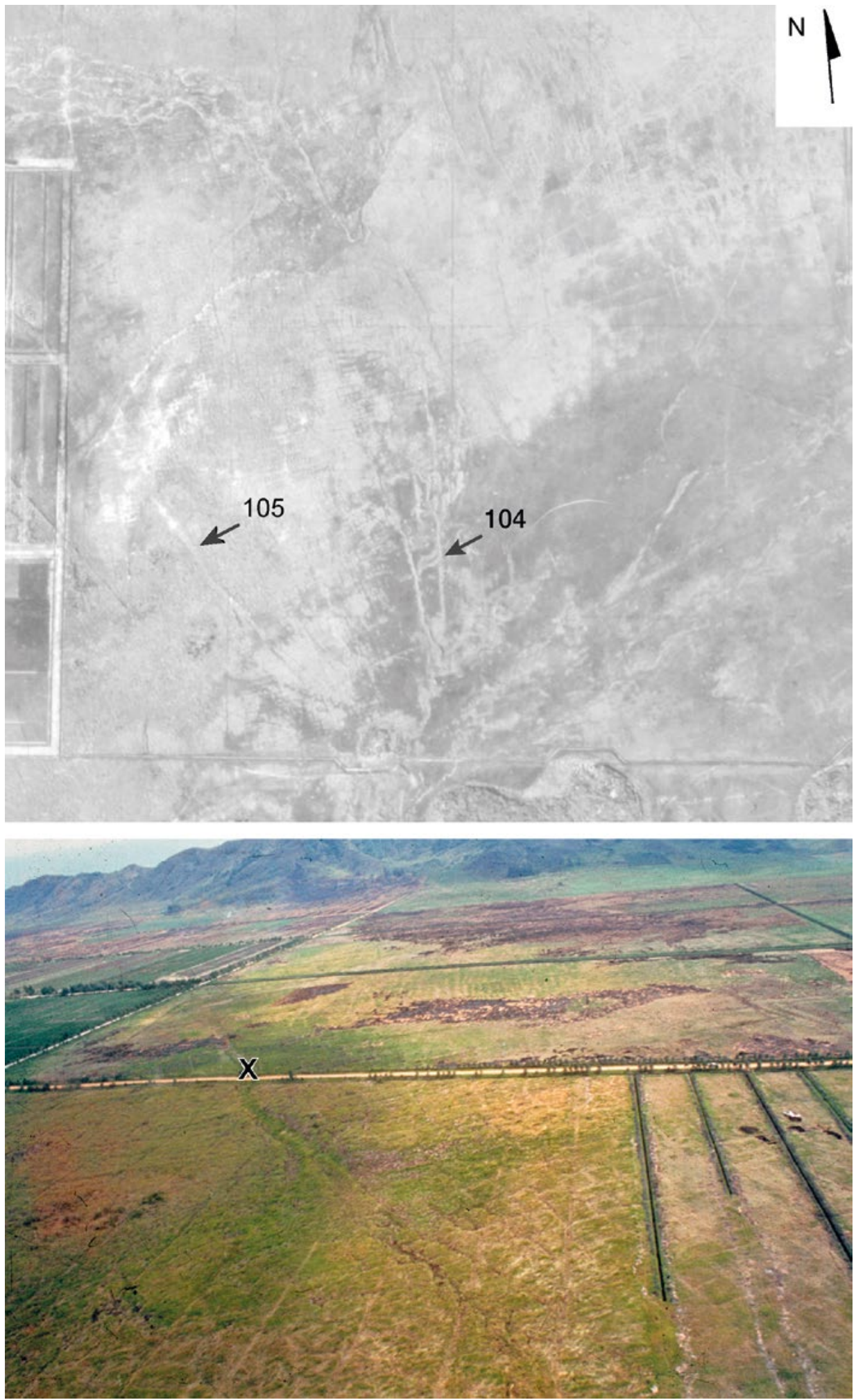

Figure 12.3 Early Phase 2 palaeochannel courses at Kuk from the air.

The vertical photograph (top) depicts the courses of channels 104 (William's Baret) and 105 (Kupalg's Baret); and the oblique photograph (bottom) shows the NNW course of channel 105 crossing E-W Rd 1 from block A8 to block B7, ' $x$ ' marks the location of Figure 12.6.

Source: Upper photograph by Mapmakers January 1970, Run 24, reproduced with permission; lower photograph by Wal Ambrose, Kuk archive, 1972. 
a) channel 109

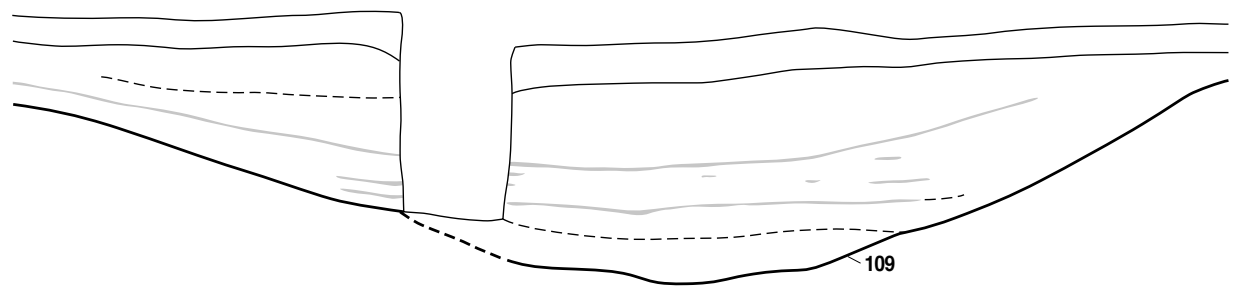

b) channel 104

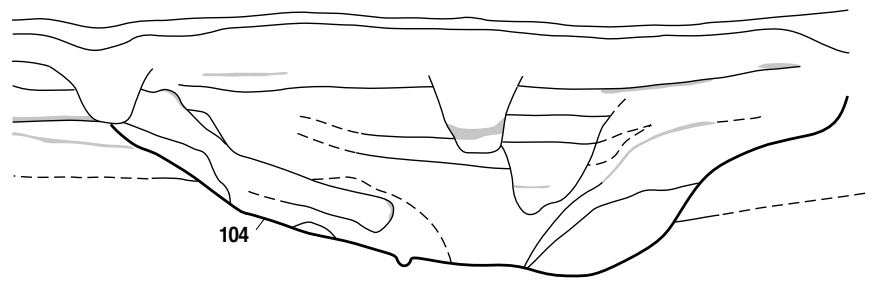

c) channel 105

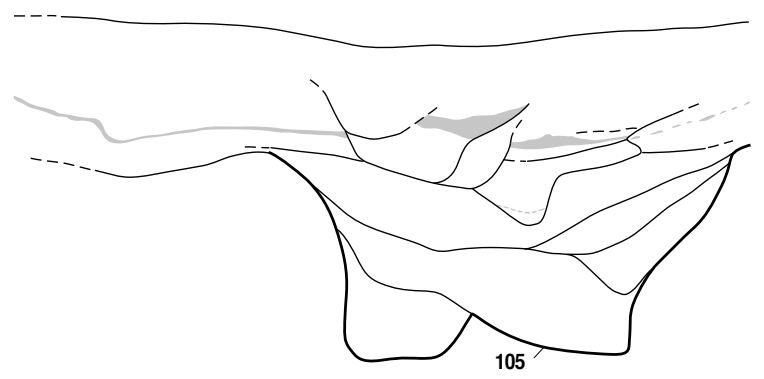

d) channel 107

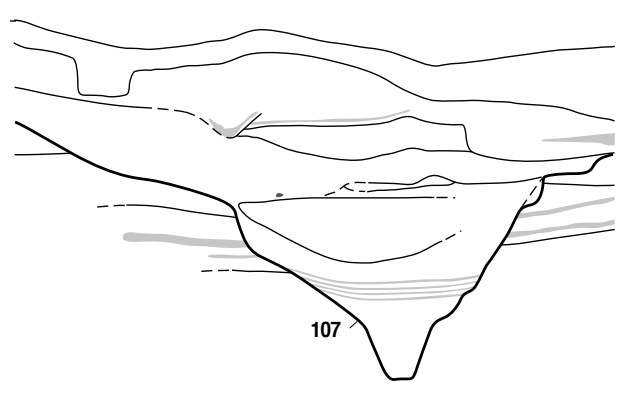

e) channel 103

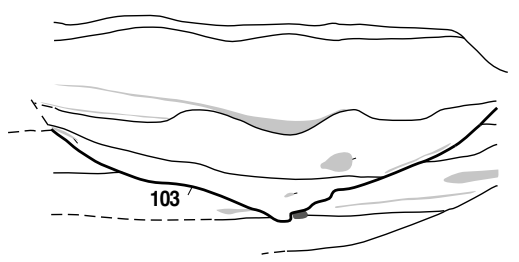

Figure 12.4 Typical cross-sections of Phase 2 palaeochannels.

Source: Drawing reconstructed by Tim Denham from the fieldnotes of Philip Hughes and Jack Golson. Reproduced with permission from Denham, Golson and Hughes (2004: Fig. 5). 


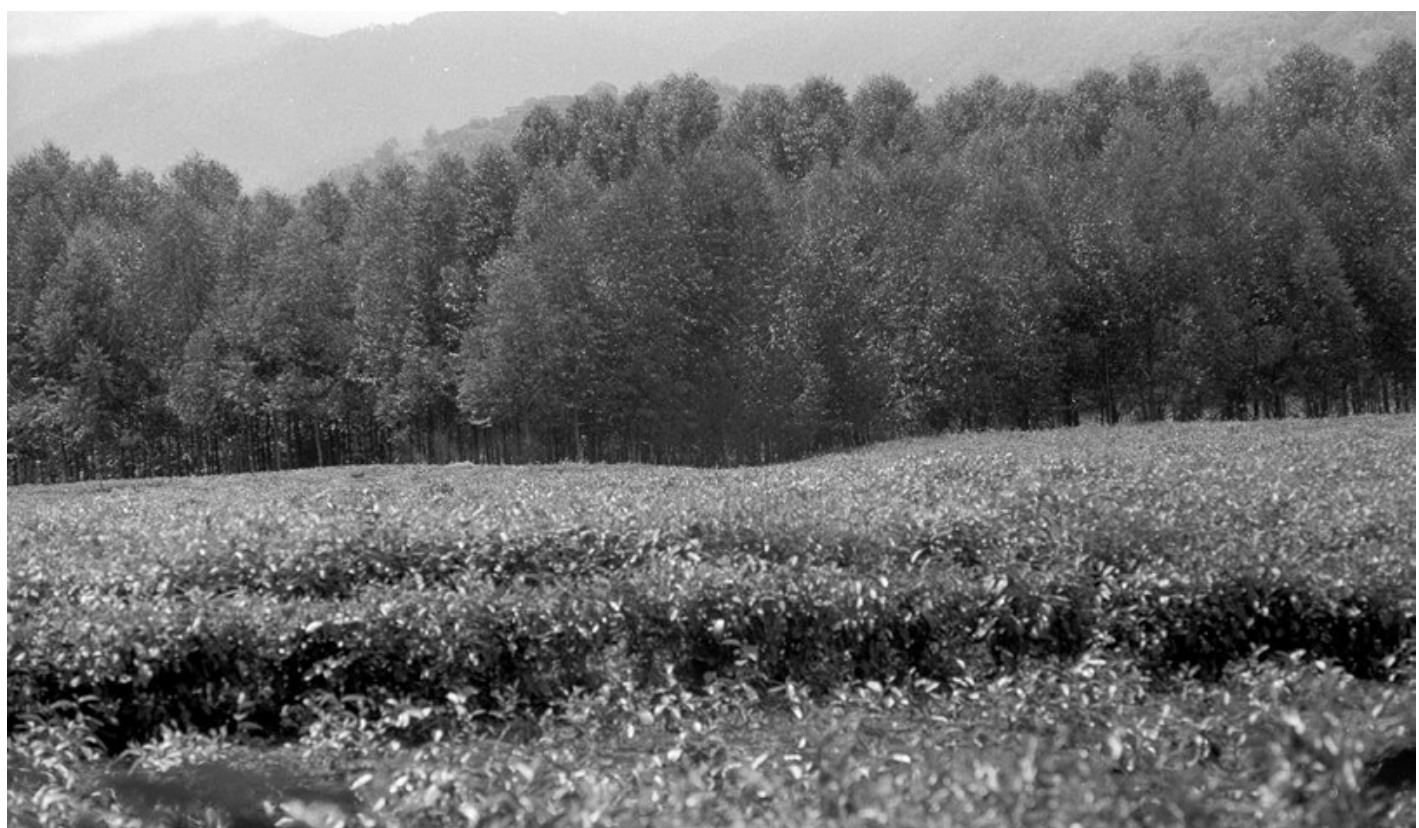

Figure 12.5 Looking south from E-W Rd 3 to a surface dip that marks channel 105 (Kupalg's Baret) crossing a hillock in block $\mathrm{C6}$.

Source: Photograph by Jack Golson, Kuk archive, 1975.

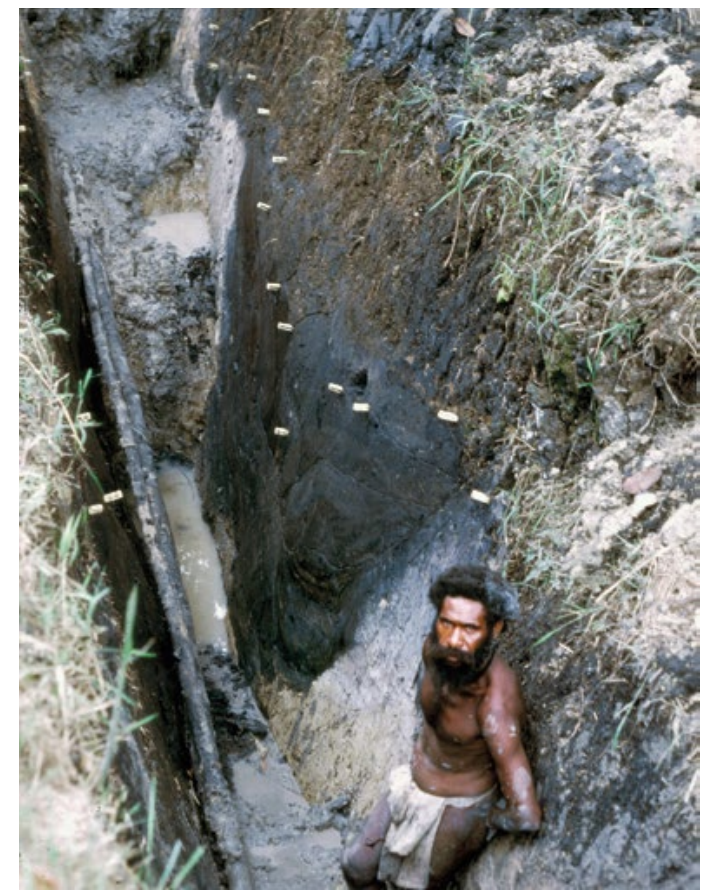

Figure 12.6 Kupalg's Baret (channel 105) exposed in profile in the north wall of the north drain of E-W Rd 1.

Korowa of Kuk village stands on the bottom of the road drain, part of which he has dug out to expose the section across the channel and its fill. The location is indicated by an ' $x$ ' on Figure 12.3 (lower).

Source: Photograph by Philip Hughes, Kuk archive, 1975.
In summary, it remains a matter of debate whether the palaeochannels associated with early Phase 2 are artificial. Irrespective of their mode of formation, there is no direct association between the palaeochannels and palaeosurface. In contrast to Phase 1, in which the investigated palaeosurface was immediately adjacent to the palaeochannel, early Phase 2 palaeochannels are located over $300 \mathrm{~m}$ west of areas where the contemporary palaeosurface has been excavated (Denham, Golson and Hughes 2004: 287). Any association between palaeochannels and palaeosurface during early Phase 2 is indirect; that is, palaeochannels allowed human use of the southern portion of the wetland margin because they limited flooding by incident water from the southern catchment and aided local drainage. 


\section{Palaeosurfaces}

Early use of the palaeosurface at the top of grey clay was restricted to the southern portion of the wetland margin, being largely limited to the A blocks and the southern portion of the B blocks. It is assumed that areas to the north were lower and too wet to use at this time. Excavations targeted on the early palaeosurface revealed two distinct types: 'integrated' and 'discrete'. The integrated palaeosurface consists of regular to semi-regular networks of features dug into grey clay, which defined upraised 'islands' at the surface of grey clay (Figs 12.7 and 12.8). The discrete type is in some places suggestive of denudation and truncation of more integrated forms, whereas in other areas scattered features suggest different and less intensive practices taking place between integrated plots (Figs 12.9 and 12.10). Many of the features are shallow and fills are not clearly differentiated from the main black clay stratigraphic unit (Fig. 12.11), except where basal R+W lenses are present. Multiple lines of evidence indicate early palaeosurface types to be associated with human activities and, more specifically, with cultivation.

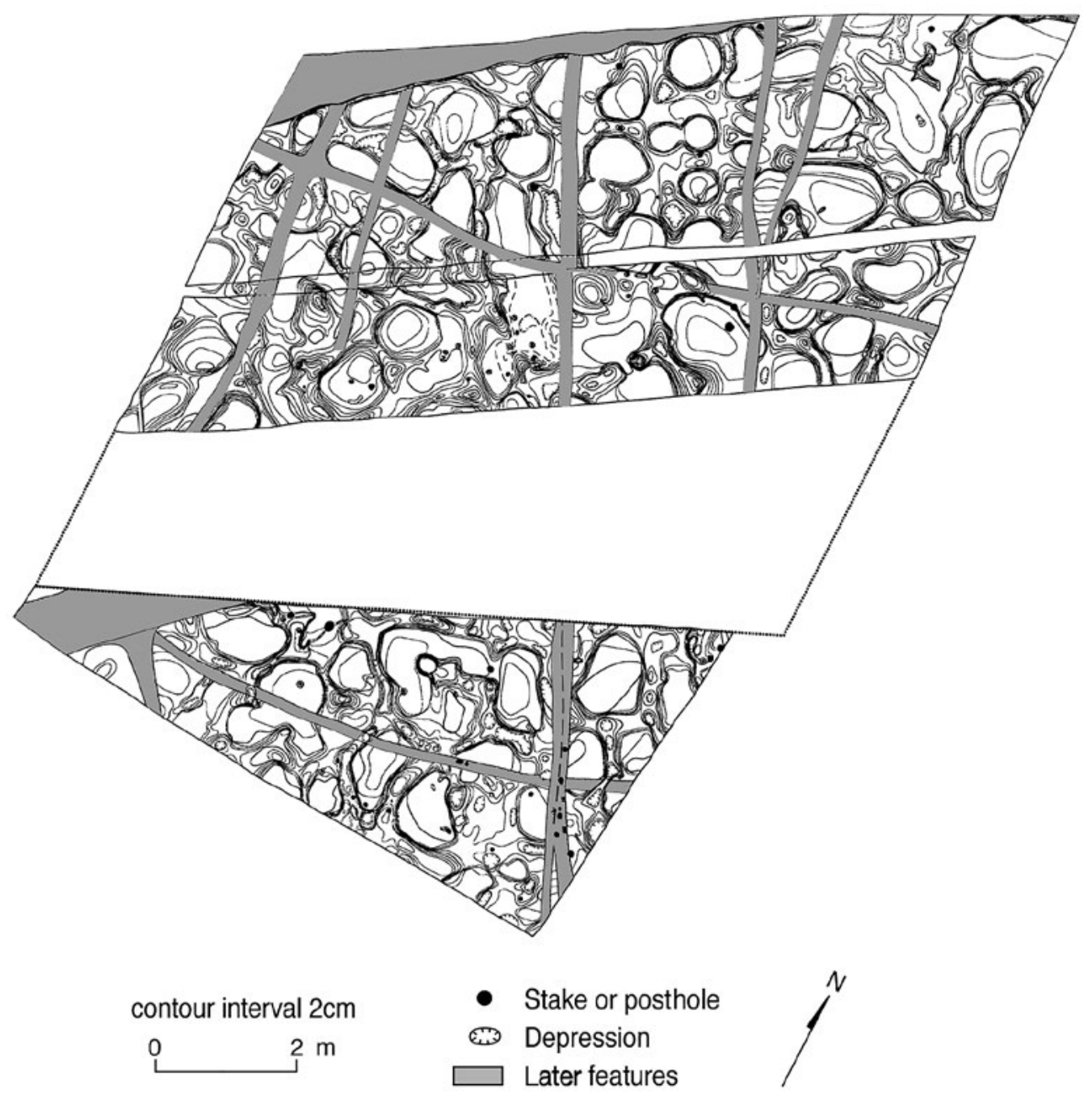

Figure 12.7 Base plan of two excavation trenches at the north end of block A11f showing the 'integrated' type of early Phase 2 palaeosurface.

Originally, the more northerly of the two excavation trenches was dug as two separate trenches, one in 1976 (see Fig. 12.8), the other in 1977, parallel to the first but initially separated from it by a narrow baulk. The triangular cutting to the south was excavated in 1977. Note the use of different datums for the northerly and southerly trenches.

Source: GIS image prepared by Uri Gilad from a contour plan of 1977 by Art and Cherie Rohn. 

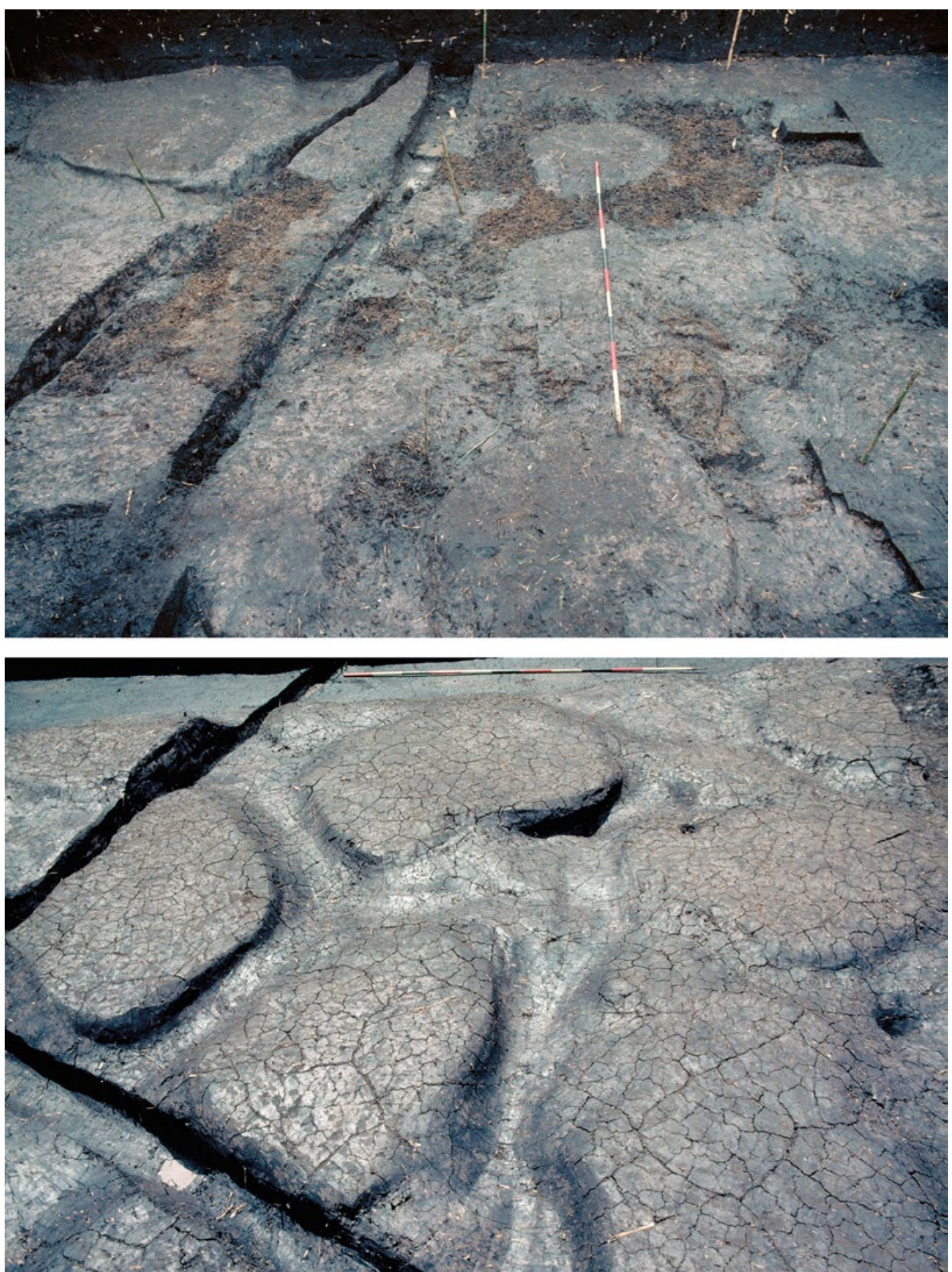

Figure 12.8 The first trench of the Phase 2 excavations shown in Figure 12.7: (upper) grey clay 'islands' contrast with surrounding fills with their lenses of R+W (Komun), looking $S$; and (lower) grey clay 'islands' are clearly defined following removal of the surrounding fills, looking $N$. The linear features crossing the palaeosurface are garden ditches of a later date. Ranging poles are calibrated at $200 \mathrm{~mm}$ intervals.

Source: Photographs by Alistair Marshall, Kuk archive, 1976. 


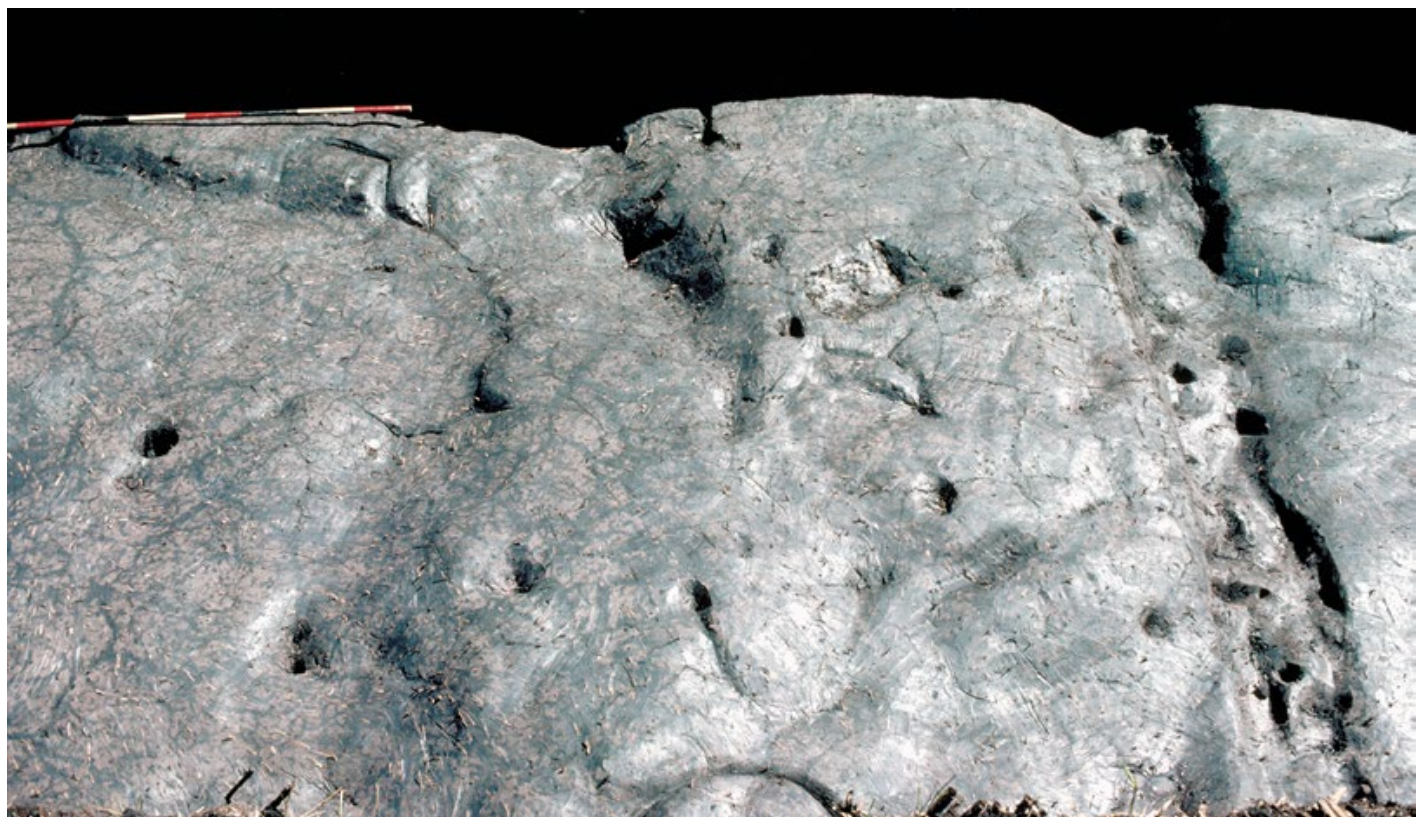

Figure 12.9 An excavation at the northern end of block A11h provides an example of the 'discrete' type of early Phase 2 palaeosurface.

The juxtaposition of various feature types, like shallow saucers and deeper pits, and the association of post and stakeholes are reminiscent of the Phase 1 palaeosurface shown in Figure 11.12.

Source: Photographs by Alistair Marshall, Kuk archive, 1976.

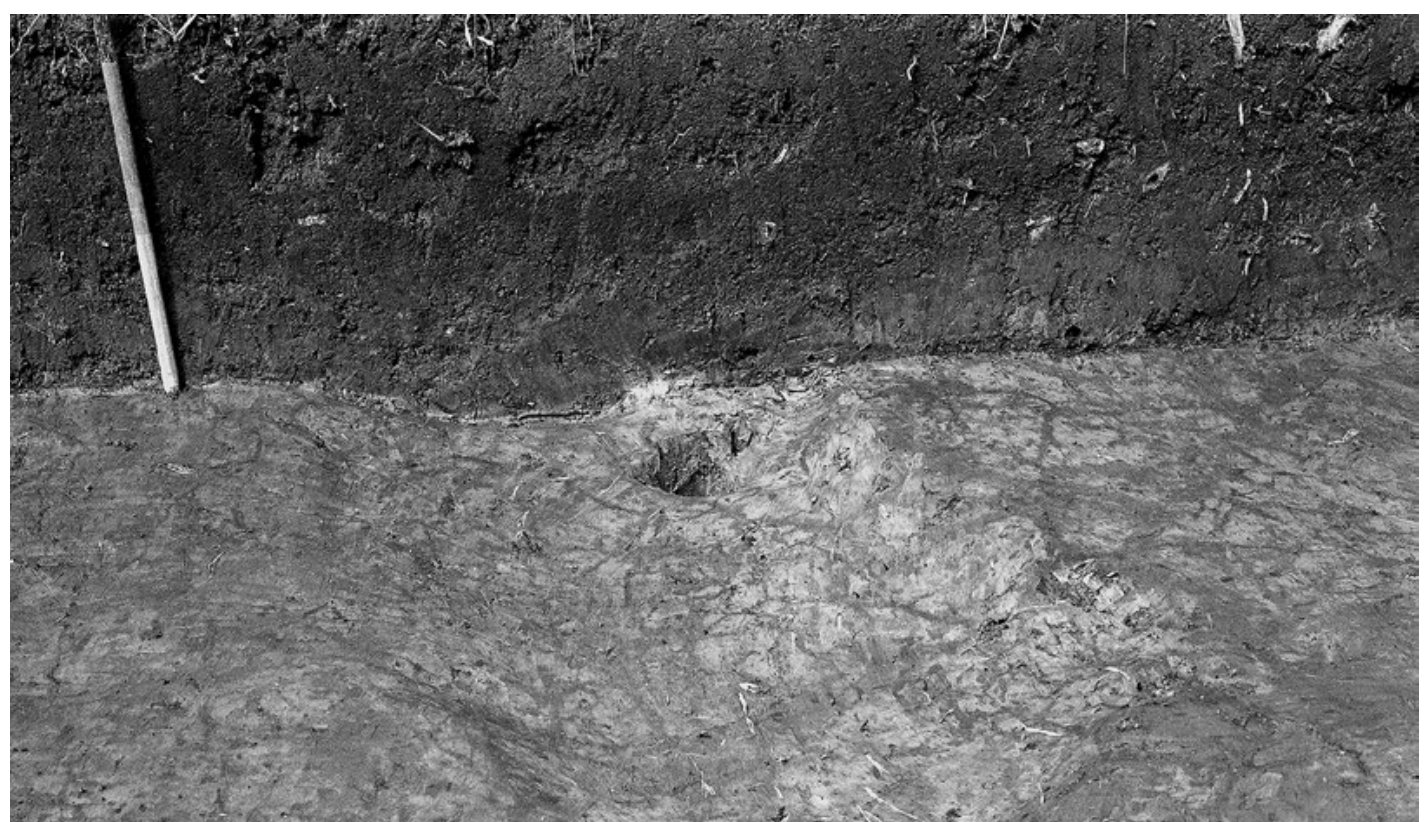

Figure 12.10 Looking west over a shallow pit with stakehole in the NW corner of an excavation at the northern end of block A12d (see Fig. 15.10).

At the time, the presence of a stakehole with a shallow pit was seen as providing strong support for the presence of pigs, because the contemporary tethering of pigs produced the same combination of features in the ground (cf. Denham, Golson and Hughes 2004: 284). Ru Kundil of Kuk village, who witnessed the excavation, thought so too, exclaiming (in pidgin) 'They staked a pig here!'. This interpretation is no longer current, given that pigs were probably introduced to New Guinea within the last 3000 years (see Chapter 15).

Source: Photograph by Klim Gollan, Kuk archive, 1975. 


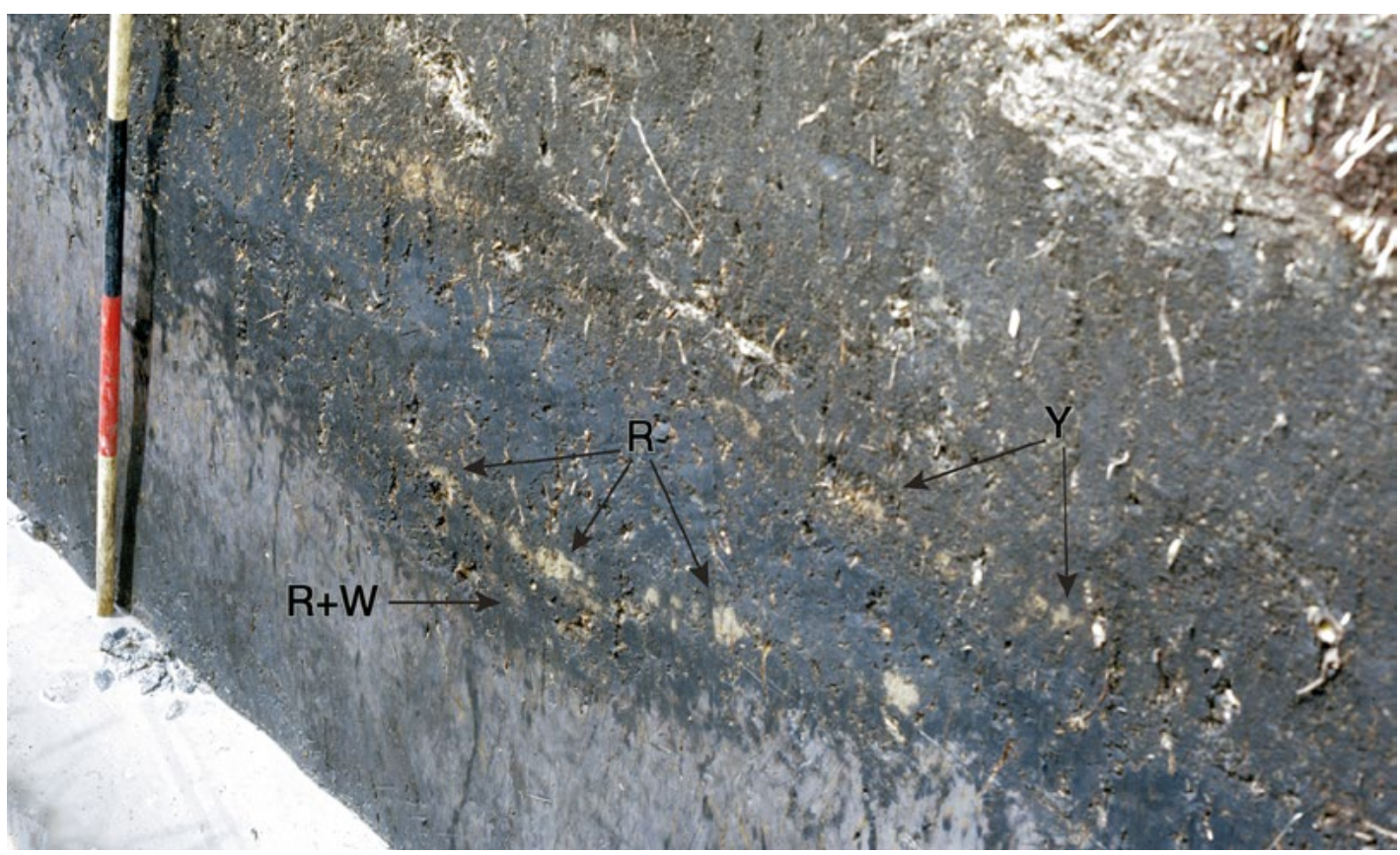

Figure 12.11 This basin-like depression in the top of grey clay is typical of how Phase 2 features appear in the walls of modern drains that cut across them, in this case the west wall of drain A11d/e.

In the stratigraphy, there is a discontinuous lens of Kim (R) ash dipping to $100 \mathrm{~mm}$ above the base of the basin and a similarly discontinuous but level-lying stretch of Baglaga $(\mathrm{Y})$ ash above the northern rim of the basin at the transition from clay to soil. There are a few traces of $\mathrm{R}+\mathrm{W}$ (Komun) below Kim. The ranging pole is graduated at $200 \mathrm{~m}$ intervals, although here the white segment above the metal point of the pole is partially obscured by mud.

Source: Photograph by Jim Rhoads, Kuk archive, 1974.

The highly regular form of the 'island beds' are more suggestive of artificial than natural formation and appear to be of human origin (see Figs 12.7 and 12.8). Non-human modes of formation were considered, particularly given the morphological resemblance of feature types to known microtopographic forms. For example, integrated and discrete palaeosurface types are morphologically comparable to network and 'melon-hole' gilgai, respectively (Hallsworth, Robertson and Gibbons 1955: 3 and 9). However, neither the geochemical and physical properties of the deposits nor prehistoric environmental conditions at Kuk are consistent with those required for gilgai formation or vertisol development (Denham 2003a: Appendix C6). The 'islands' formed the surface on which soil from the digging of adjacent subsoil features was heaped at the time of use, making mounds that have subsequently disappeared.

Repeated associations of vertical or slanting postholes and stakeholes with the deeper of the basins on the palaeosurface are considered to represent the staking of plants such as edible cane grass (e.g. Setaria palmifolia), Saccharum sugarcanes and Musa bananas and the use of branches as ladders to help with the wrapping or harvesting of bunches of bananas (Figs 12.12 and 12.13; Gorecki 1982: 206-208). The planting of other crops and the staking of yams and beans are unlikely to leave archaeological traces (Gorecki 1982: 206 and 209 respectively). 


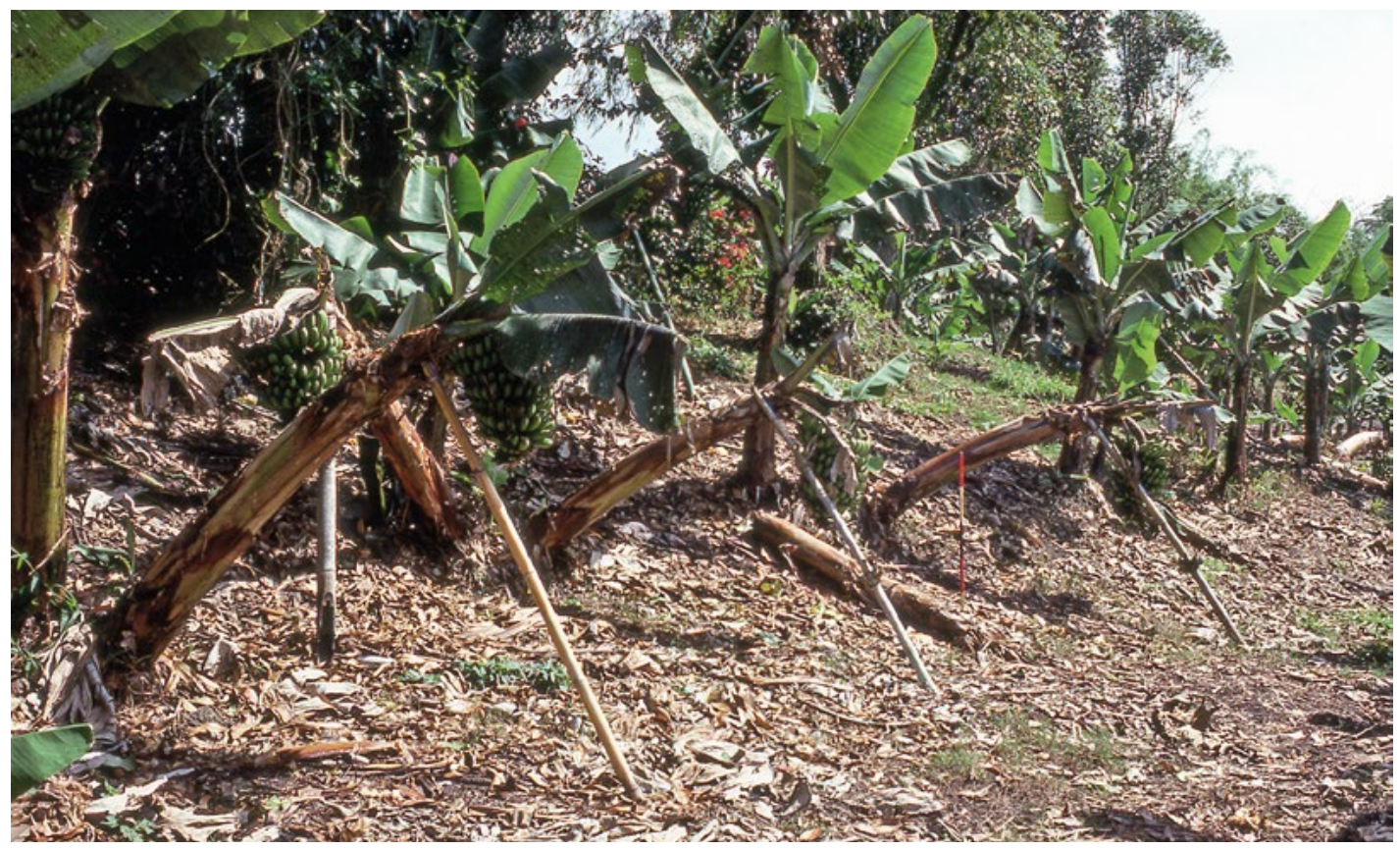

Figure 12.12 Stakes propping up banana plants at the Highlands Agricultural College, Korn Farm, Mount Hagen.

Source: Photographer unknown, the Kuk archive, 1977.

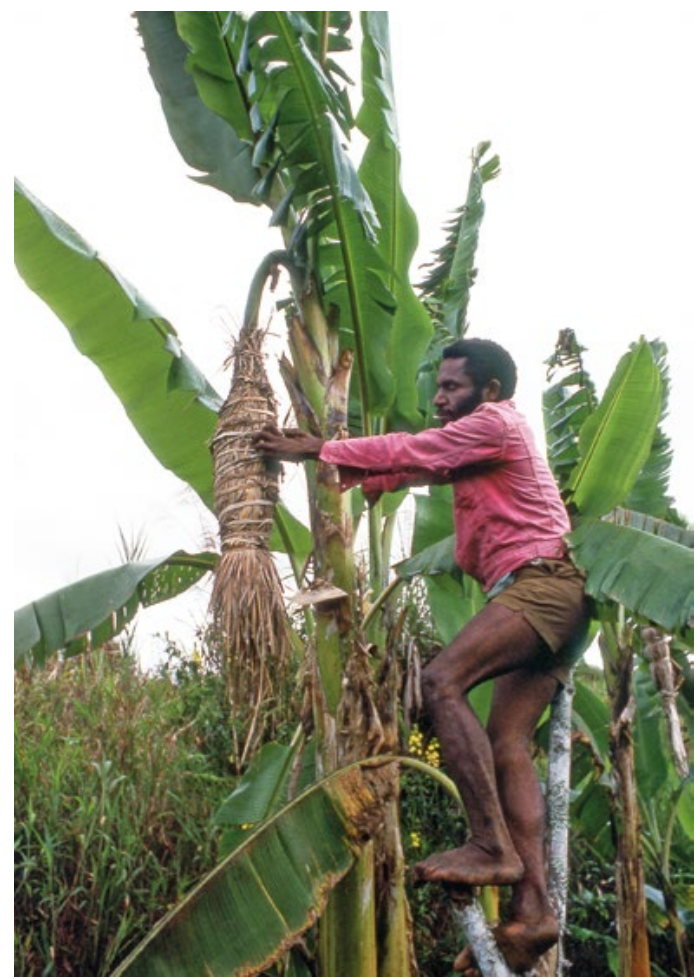

Figure 12.13 William Thomas on a tree ladder attending to the wrapping of bananas in his garden near Mt Ambra.

Source: Photographer unknown, the Kuk archive, 1977.
Artefacts and manuports, although sparse, were collected from contexts associated with the early palaeosurface (see Chapter 20, section 'Phase 2'; cf. Fullagar et al. 2006: 607-609, where the artefact catalogued $\mathrm{K} / 76 / \mathrm{S} 19$ is wrongly attributed to Phase 3). Stone tools exhibit evidence for the processing of Colocasia taro and of palms (and, less likely, gingers), as well as for the presence of unidentified plant residues. These artefacts show that people were exploiting plants, including starch-rich root crops, when the mounded palaeosurface was used.

Evidence for the cultivation of bananas has been recovered from the fills of palaeosurface features (see Textbox 10.2). Locally elevated Musaceae phytolith levels (see samples 35, 36 and 37 of Table 10.1 and Fig. 10.T2.1) are interpreted to represent the deliberate planting of Musa bananas within mounded plots. Lower values in other feature fills represent spatial variability in cultivated plant densities within intercropped plots, i.e. high Musaceae phytolith densities were derived from the in situ death and decomposition of banana plants and plant parts. Analyses of plant seeds in general suggest that gardens and garden fallow were located in the vicinity at this time (Powell et al. 1975: 42). 
Elevated charcoal levels and heterogeneous fills are interpreted as local burning and mechanical admixture. Burning may have accompanied initial clearing or reuse of the plot prior to mound construction and planting. Burning of vegetation enables organic nutrients to be rapidly released into the soil and provides fertiliser for the next planting. Heterogeneous feature fills are interpreted as reflecting a physical admixture of materials falling and being washed into features between mounds during construction and use. As well as intermixing, feature fills preserve characteristics associated with prehistoric soil formation that are missing from the overlying black clay.

The early integrated palaeosurface was previously interpreted as representing small-scale microtopographical manipulation of the wetland to enable the multicropping of plants with different edaphic requirements (Golson 1977a: 617). Water-tolerant plants, such as Colocasia taro, were potentially planted along the edges and in the bases of the palaeosurface drainage network, while water-intolerant plants such as Saccharum sugarcanes, Musa bananas, yams (Dioscorea spp.), edible pitpit (Setaria palmifolia) and mixed vegetables were planted and staked on the 'island beds' (after Powell et al. 1975: 42; Golson 1977a: 616, 1981: 57-58). Archaeobotanical finds confirm the presence of several important food plant species in the highlands by the mid Holocene (Denham et al. 2003; Denham 2003a: 311-328).

Recent research shows that although edaphic requirements were almost certainly a consideration in mound construction, the network of cut features did not contain permanent standing water. Diatom assemblages within the fills of palaeosurface features indicate damp conditions (Denham, Sniderman et al. 2009: 730-731). Based on this finding, mounds provided raised areas for the cultivation of moisture-intolerant plants and facilitated drainage during periods with standing surface water, which would have periodically collected above the massively structured clays in this flood-prone location (Denham, Sniderman et al. 2009: 737).

\section{Landuse}

The palaeoecology of the Kuk vicinity underwent a dramatic transformation at the beginning of Phase 2 (Denham, Haberle and Lentfer 2004; Haberle et al. 2012; and see Chapter 9 here). The forest signal drops significantly and is accompanied by dramatic increases in grass taxa frequencies. Associated charcoal frequencies suggest the formation and management of grasslands on the valley floor using fire, with only isolated stands of forest surviving on higher valley slopes (Denham and Haberle 2008). Thus, the formation and maintenance of extensive grasslands was a product of human activities and such degraded environments are characteristic of presently and recently cultivated areas across the highlands today. Mounded cultivation on the wetland margin occurred within such an open grassed landscape and was maintained by periodic burning. The maintenance of an anthropic landscape, for both the dryland and wetland environments, is suggestive of cultivation in the highlands context, but the dryland agricultural practices occurring at this time remain uncertain.

\section{Late subphase: Cultivation before Kim ashfall, predating 3980-3630 years ago}

The late subphase has three main components: palaeochannels, palaeosurface features and at least three composite features with linear and sinuous plans. Limited investigation of the late subphase hinders detailed interpretation, but the constituent features are analogous to those of the early palaeosurface and are interpreted in a similar way.

\section{Palaeochannels}

Two artificial palaeochannels, Kum's Baret (103) and Joseph's Baret (107), are definitely associated with the late subphase because both contain lenses of Kim tephra (R) low down in their fill (Fig. 12.4d and 12.4e), although channel 107 continues in operation beyond into early Phase 3. 
A possible third palaeochannel is Kui's Baret (102), which could equally be early or mid Phase 3, under which it is discussed (see Chapter 13). The stratigraphic evidence to indicate the age of channel 102 was removed when channel 106 (a later cut of Kui's Baret) was dug.

Channels 103 and 107 differ in plan and cross-section from those of the early subphase. In plan, they follow extremely straight courses adjacent to each other across the southern wetland margin (see Fig. 12.2). In cross-section, they exhibit steeper U- to V-shaped cross-sections than those associated with the early subphase (compare Figs 12.4a, 12.4b, 12.4d, 12.4e). Both palaeochannels cut through low rises on the present-day landscape. It is uncertain whether people deliberately dug through these low rises in order to align the course of the channel, an interpretation proposed by Golson and Hughes, or whether the rises result from differential lowering of the ground surface due to sediment drying, shrinkage and erosion following recent drainage; namely, the rises did not exist at the time the palaeochannels were dug, the interpretation proposed by Denham (see Denham, Golson and Hughes 2004: 282, cf. 269-274). Irrespective of these differing interpretations, both palaeochannels were dug to enhance and regulate water flow and to prevent inundation of the wetland margin.

Late subphase palaeochannels do not appear to have articulated directly with the palaeosurface. Few Kim (R) ash-marked features of the late subphase were encountered in excavations adjacent to channels 103 and 107 . As with the early subphase, the late subphase palaeochannels would have modified the hydrology of the wetland margin sufficiently to enable cultivation of the palaeosurface.

\section{Palaeosurface}

The late palaeosurface was preserved north of its early subphase equivalent; the greatest density of features occurred in B and C blocks. The palaeosurface has been recorded mainly in plantation drains with few occurrences in excavation trenches. It is unclear whether late subphase features form discrete or integrated palaeosurface types. Late subphase features appear to be more subangular in cross-section and more linear in plan than the rounded and sinuous features of the early subphase. Based on morphology, the features probably functioned in similar ways to those of the early palaeosurface and were dug to enable cultivation of plants with different edaphic requirements.

Two relatively straight linear features (328 and 355) and a sinuous curvilinear feature (504) were documented during excavations near palaeochannels 103 and 107 in blocks A12a and A12b (Fig. 12.2), though none of them was shown to articulate with either channel. The two linear features were extremely shallow, contained lenses of Kim tephra (R) and cut early subphase features marked by lenses of $\mathrm{R}+\mathrm{W}$ ash. Both linear features were poorly documented during the original excavations in 1975 and not clearly defined during reexcavation in 1999.

The sinuous curvilinear feature 504 was well defined by excavations undertaken by Golson in 1976, 1977 and Denham in 1999. It was a composite feature consisting of a string of basins connected by short channel sections with rounded (concave) bases and sides (Figs 12.14 and 12.15). It is interpreted to be a prehistoric garden feature that contained an admixture of dense macrocharcoal, soil and subsoil aggregates and extremely high Musaceae phytolith frequencies (see samples 55 and 56, Table 10.2). All this suggests that cultivation occurred in the immediate vicinity and included clearance of grasslands using fire, physical disturbance of the ground surface, potentially to break up dense grass root mats, and planting of bananas with other crops in the same plot. As for the garden feature itself, Golson thinks it has a structural resemblance to the basins and interfluves of the integrated Phase 2 palaeosurface, though on a linear rather than an areal plan, and may have been used for the cultivation of moisture-tolerant crops like taro. 


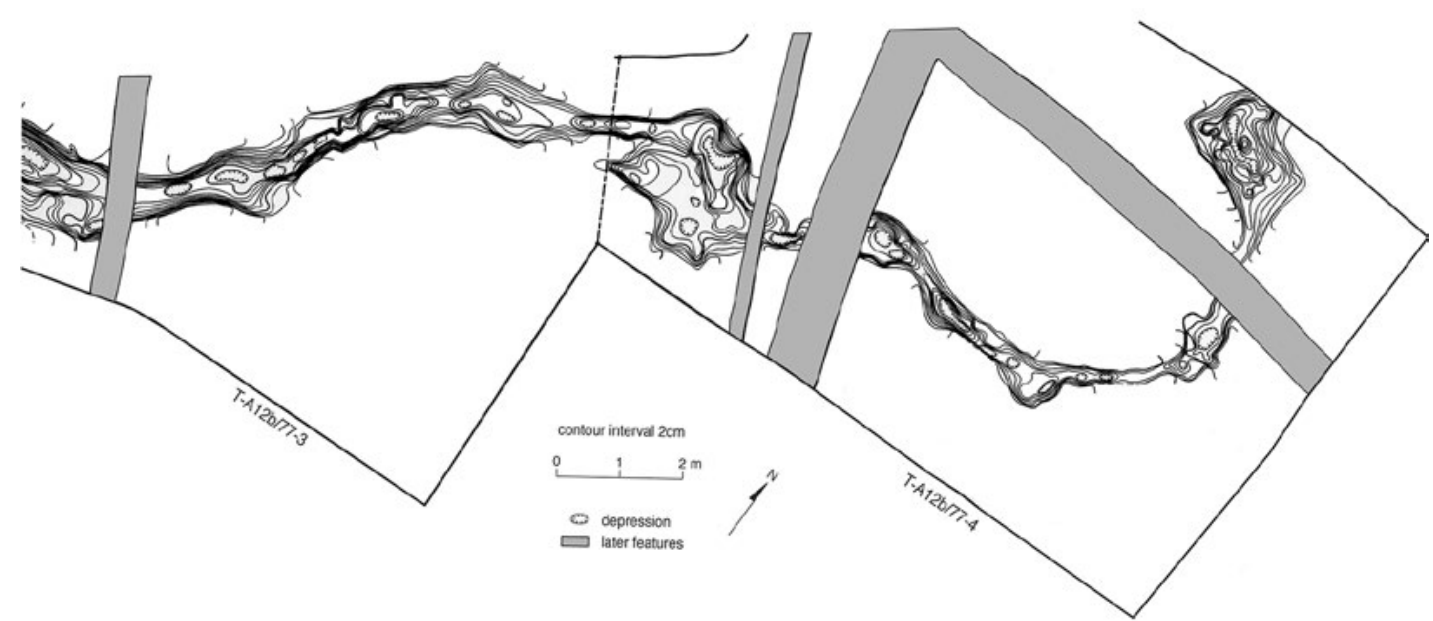

Figure 12.14 Plan of the sinuous curvilinear feature 504 of late Phase 2 age in the northern part of block A12b.

Source: Digitised by Uri Gilad, based on the original field plan drawn by Art and Cherie Rohn, 1977.

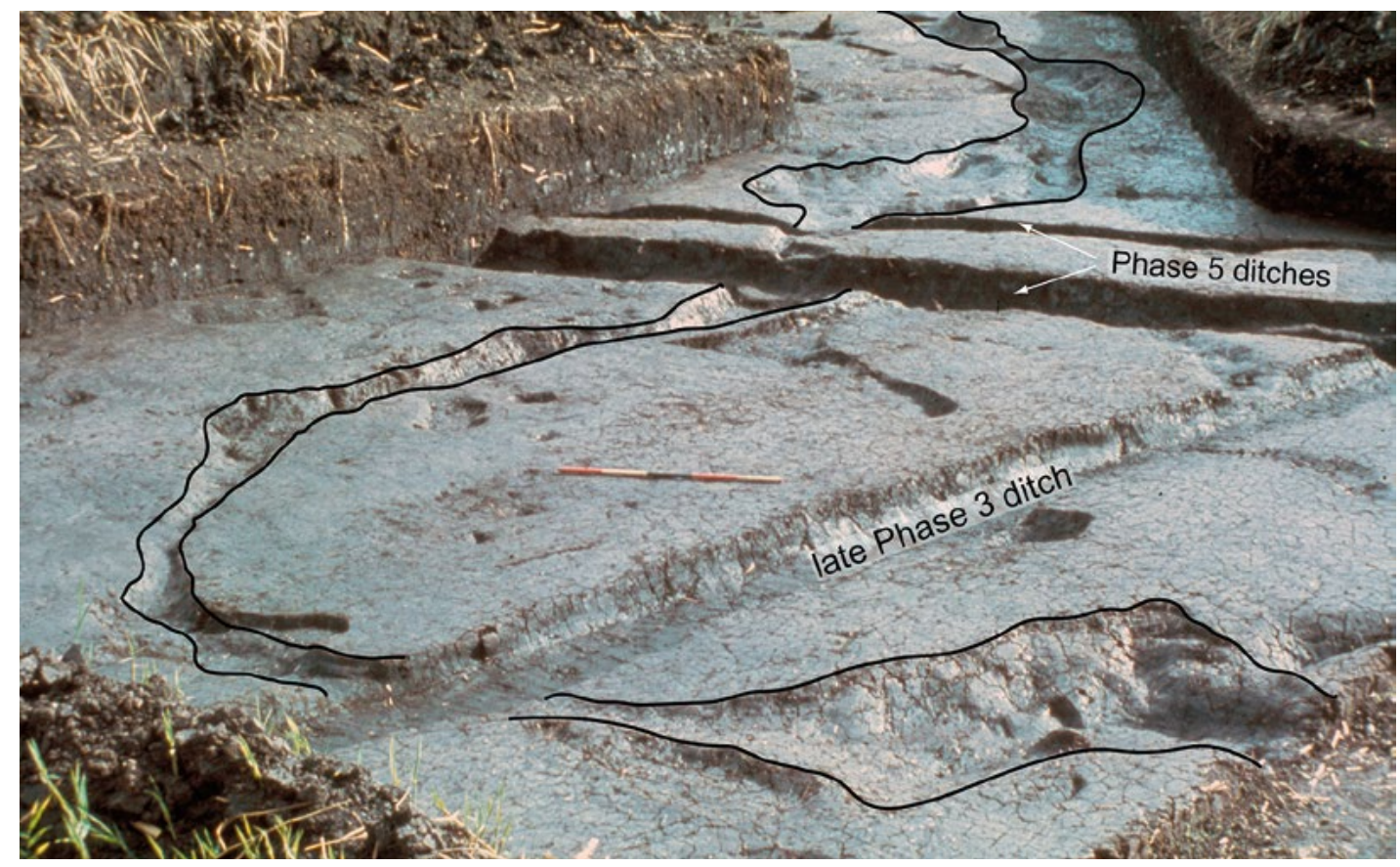

Figure 12.15 Looking SW along the line of sinuous curvilinear feature 504 . The ranging pole is graduated at $200 \mathrm{~mm}$ intervals.

Source: Photograph by Ed Harris, Kuk archive, 1977.

\section{Landuse}

The palaeoecology at Kuk during the late subphase was similar to that of early Phase 2, namely the valley floor in the vicinity of Kuk was carpeted with grassland maintained by periodic burning (Denham, Haberle and Lentfer 2004; Haberle et al. 2012; Chapter 9 here). There is considerable continuity between the two subphases in terms of feature morphologies. Most features in both subphases are rounded in plan and section; they form complexes with curvilinear or sinuous plan forms. There are two palaeochannels, in the late subphase, which are the earliest to be unarguably considered artificial by Denham, Golson and Hughes, as well as three straight or curvilinear 
alignments of human construction. These palaeochannels and alignments are potentially of great significance for understanding the emergence of rectilinear ditch networks in Phase 3. At present, more research is needed to clarify the transition between Phases 2 and 3 at Kuk and other wetland sites.

\section{Regional processes in the upper Wahgi Valley and beyond}

Palaeosurfaces similar in form to the early integrated type at Kuk have been documented in excavations at two other wetland sites in the upper Wahgi Valley (Golson 1982: 121; Denham 2003b: 170-173). More equivocal evidence has been claimed to represent former agricultural activities of similar type and age at Kana near Minj (Muke and Mandui 2003) and on the Ruti Flats (Gillieson, Gorecki and Hope 1985).

As mentioned in Chapter 1, the 1966 excavations by Golson, Lampert and Ambrose at the Manton site on Warrawau Tea Estate on the floor of the upper Wahgi Valley, some $6 \mathrm{~km}$ across the Wahgi River from Kuk, provided the first direct evidence of the age of New Guinea agriculture (Golson et al. 1967; Lampert 1967; see Figs 12.16 and 12.17 here). A woman's digging stick yielded a radiocarbon date that calibrates to between 2000 and 2500 years ago, well before the entry into New Guinea of the tropical American sweet potato that is the present staple of highlands agriculture.

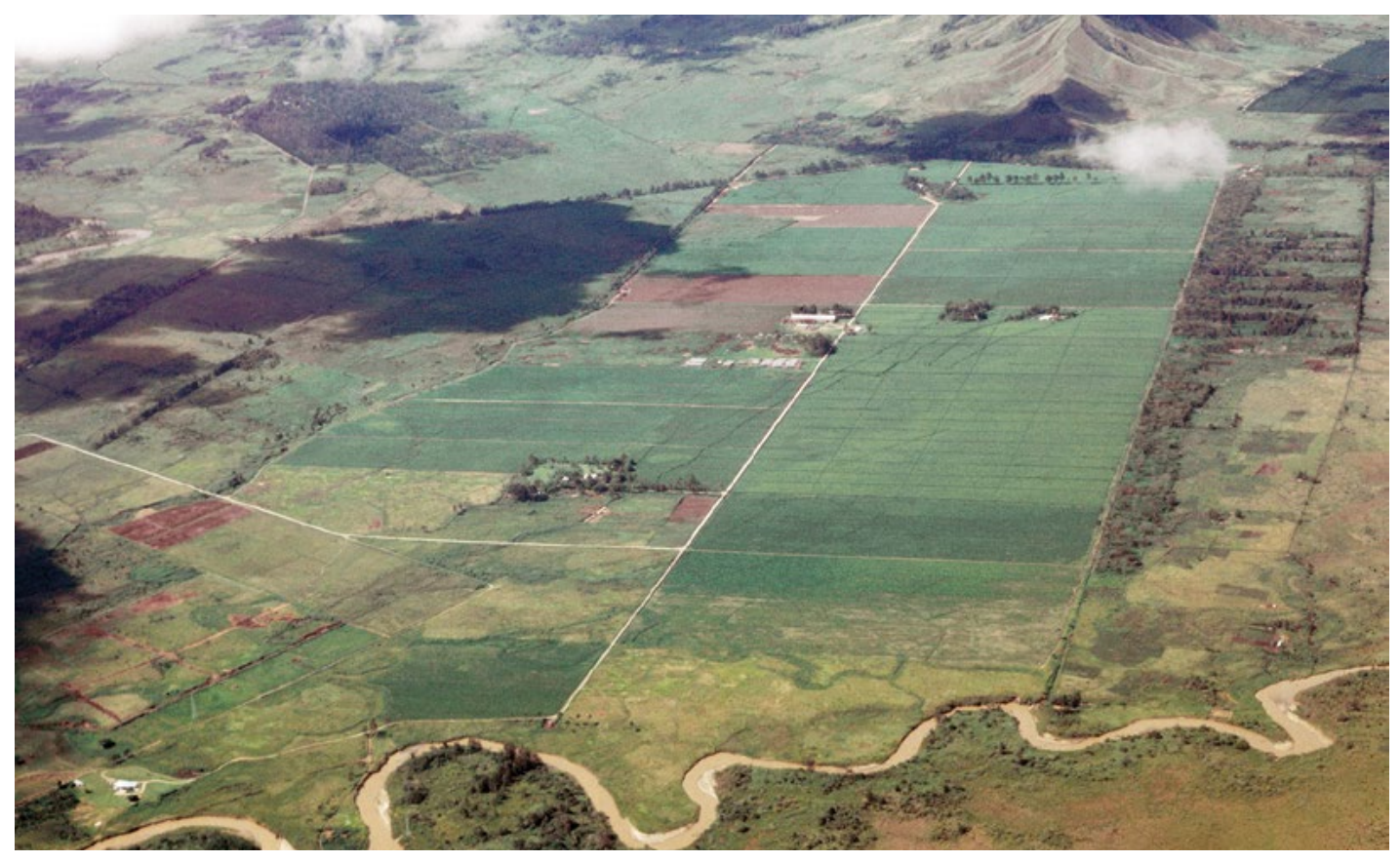

Figure 12.16 Aerial view of Warrawau Tea Estate in the upper Wahgi Valley looking SE from the river to the foothills of the Kubor Range.

Source: Photograph by Philip Hughes, Kuk archive, 1975.

In 1977, Golson and Hughes redug four of the original 1966 trenches at the Manton site in order to reexamine the ditch sequence in relation to that established at Kuk (Fig. 12.17; Golson 2002). A palaeosurface of similar form to the early Phase 2 palaeosurface at Kuk was present in one excavation trench (Trench M). Although of similar form, the 'islands' of grey sandy clay at Manton were much steeper and higher than those unearthed at Kuk (Fig. 12.18). In two other reexcavated trenches (Trenches $\mathrm{C}$ and $\mathrm{D}$ ), a feature formerly interpreted to be a pond was investigated and found to be a palaeochannel. Fragments of gourd exocarp, originally interpreted to be bottle gourd (Lagenaria siceraria; Powell 1970a: 144-145), but now thought more likely 
to be wax gourd (Benincasa hispida; Golson 2002: 74), were collected from near the base of this palaeochannel. Radiocarbon dates and tephrochronology indicate that the palaeosurface and palaeochannel at Manton predate Kim tephra (R ash) and probably date to approximately 5500 5000 years ago (Golson 2002). Although of similar age, it is not known if the palaeochannel and palaeosurface were in use at the same time.

Also in 1977, Ed Harris and Philip Hughes (1978) conducted open area excavation and test pitting at Mugumamp Ridge in the North Wahgi swamp some $8 \mathrm{~km}$ east-northeast of Kuk. They uncovered a palaeosurface comparable to that of early Phase 2 at Kuk, comprising basins, 'islands' and postholes (Figs 12.19 and 12.20). Based on site stratigraphy and specifically the location of $\operatorname{Kim}(\mathrm{R})$ ash in the fills of features, the palaeosurface at Mugumamp is at least 4000 years old and may postdate late Phase 2 at Kuk (see Table 12.1). The association between the palaeosurface and a ditch encountered in the main excavation trench at Mugumamp is uncertain. Harris and Hughes (1978: 440-442) consider them to be functionally and chronologically associated, i.e. the ditch was dug to drain water, thereby enabling cultivation of the palaeosurface. In a review of the published evidence Denham (2003b: 170-171) concluded that the ditch postdated the palaeosurface.

The three morphologically comparable palaeosurfaces at Kuk, Mugumamp and Warrawau were not contemporaneous (Table 12.1). These sites show continuity of mounded cultivation practices in the upper Wahgi Valley over millennia. Mounded cultivation on the wetland margins at all three sites occurred within a highly degraded environment in the valley, to whose formation it probably contributed.

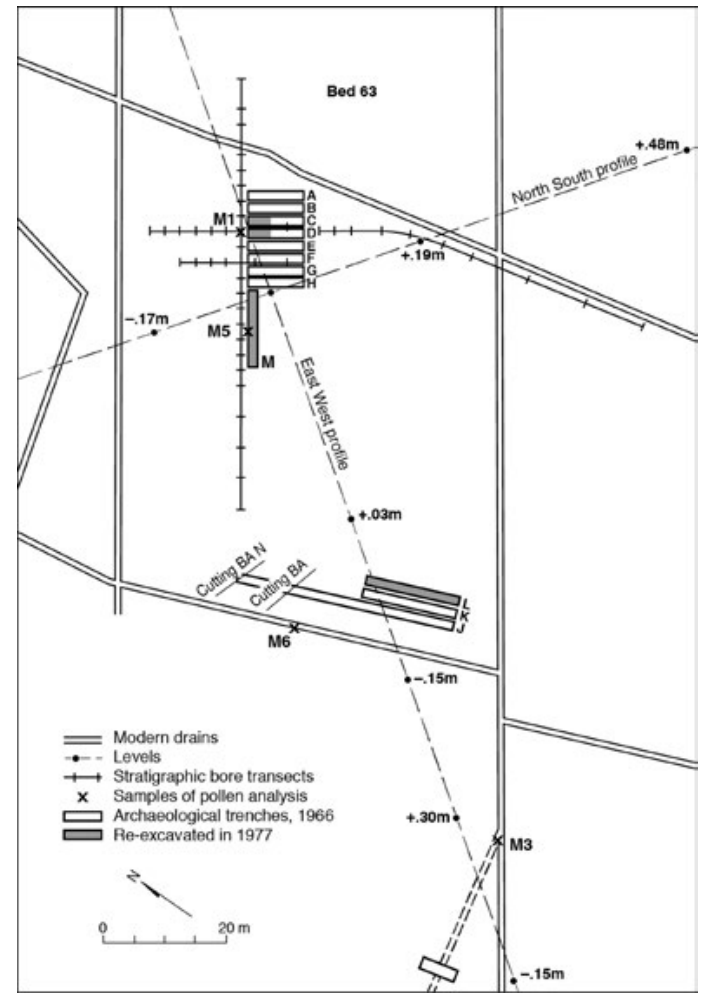

Figure 12.17 Plan of the 1966 and 1977 excavations at the Manton site on Warrawau Tea Estate.

Source: Denham (2003b: Fig. 8), amended from Powell (1970a: Fig.8.2) and reproduced with permission from Denham (2003b).

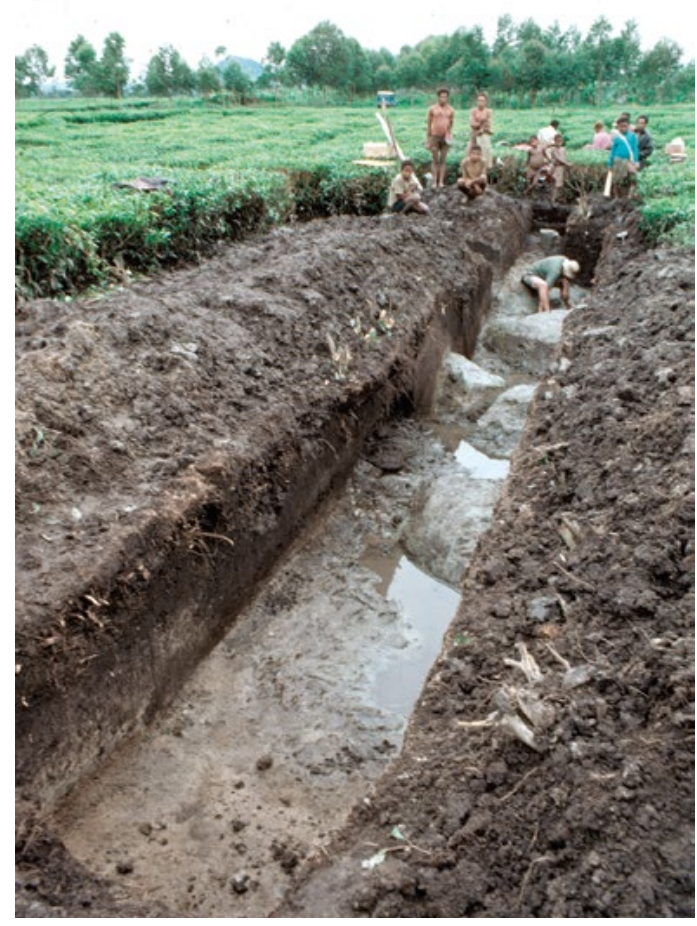

Figure 12.18 Emptying Trench $M$ at the Manton site. The excavator, Jack Golson, is exposing 'islands' of grey clay that represent the base of former mounds used for cultivation.

Source: Photograph by Ed Harris, Kuk archive, 1977. 
Table 12.1 Relative inter-site chronology for Phase 2.

\begin{tabular}{|c|c|c|c|c|c|c|}
\hline Date (cal. BP) & Deposit & Kuk $^{1}$ & Warrawau $^{2}$ & Mugumamp $^{3}$ & Kana $^{4}$ & Ruti $^{4}$ \\
\hline $3980-3630$ & Kim (R) ash & & & & & \\
\hline & & & & $X$ & & $X$ ? \\
\hline c. $4840-4440$ & & Late & & & $X$ & \\
\hline & & & & & & \\
\hline $6440-5990$ & ${ }^{\prime} \mathrm{R}+\mathrm{W}^{\prime}$ & & & & & \\
\hline $6950-6440$ & & Early & & & & \\
\hline
\end{tabular}

An ' $X$ ' denotes the presence of archaeological evidence for mound cultivation at a site and ' $X$ ?' denotes less clear, yet claimed evidence.

Source: Data collated by Denham and Golson.

Notes:

${ }^{1}$ Early and late subphase dates at Kuk are based on tephrochronology and radiocarbon dates. The late subphase date of c. 48404440 cal. BP given here for Kuk is based on the most recent radiocarbon date from feature 504 (ANU-11183; see Denham 2003a: Table F2.4). However, in this chapter and throughout this volume, this subphase is reported as pre-3980-3630 cal. BP, namely predating Kim (R) ash deposition, which is considered a more robust and secure basis than the single radiocarbon date (see Table 7.2).

2 The relative date at Warrawau is based on tephrochonology, i.e. the lie of Kim (R) ash in palaeosurface features, and on radiocarbon dates for a palaeochannel (ANU-288 and 2086; see Denham 2003a: Table 2.4).

${ }^{3}$ The relative date for Mugumamp is based on tephrochronology, i.e. the lie of Kim (R) ash at the base of palaeosurface features. ${ }^{4}$ The relative dates for Kana and Ruti are based on tephrochronology, i.e. the lie of Kim (R) ash, although the presence of Phase 2 at both sites is considered provisional (Denham 2003b: 169 and 171-172, respectively).
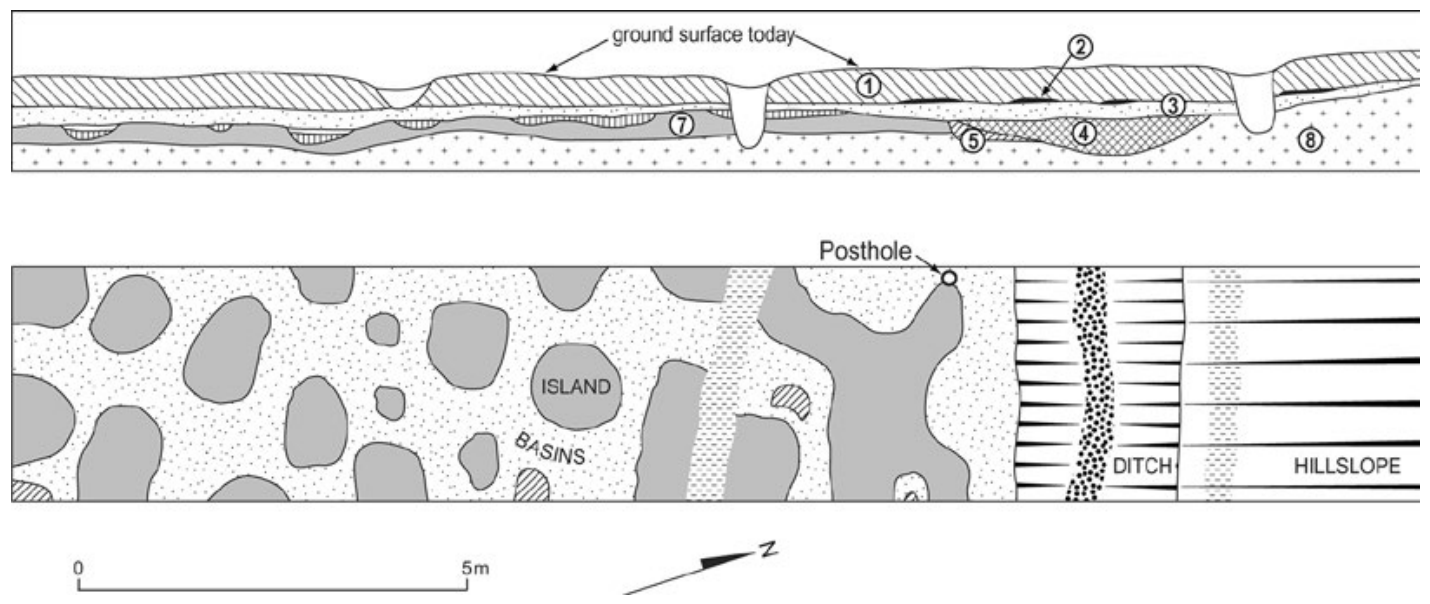

Figure 12.19 Records from the 1977 excavations at Mugumamp Ridge in the North Wahgi Swamp: (upper) the west wall section of the main trench, Trench II; and (lower) the plan of its base.

Source: Drawings from Harris and Hughes (1978: Figs 3A and 3D), reproduced with permission.

Archaeological remains of palaeosurfaces at Kuk, Mugumamp and Warrawau can be correlated with palaeoecological records for dryland activities at several sites in the upper Wahgi Valley. Palaeoecological records at Draepi-Minjigina, Ambra Crater, Lake Ambra and Warrawau, as well as Kuk, indicate significant disturbance to primary forest using fire by the mid Holocene (see Chapter 9, sections 'The early Holocene' and 'Mid to late Holocene'). At this time, the humanly created grasslands documented at Kuk were regional phenomena in the upper Wahgi Valley, although they were not ubiquitous because disturbance and regrowth communities were present at Warrawau (Denham 2003b: 173). The development of extensive grasslands maintained by burning across large tracts of the upper Wahgi Valley and the presence of disturbed communities in some locales are inferred from palaeoecology to be the result of spatially variable shifting 
cultivation on valley slopes above the wetlands (Powell 1982a: 218). In contrast to the wetland agricultural practices, no dryland agricultural sites of similar age have yet been documented archaeologically in New Guinea. The absence of archaeological sites of dryland cultivation is not surprising, however, because the valley slopes upon which these practices occurred have been denuded by a combination of erosion, mass wasting and cultivation, which are likely to have removed traces of earlier practices.

Beyond the upper Wahgi Valley, Paul Gorecki and Dave Gillieson conducted archaeological excavations on the Ruti flats of the lower Jimi Valley in the 1980s (Gillieson, Gorecki and Hope 1985; Gillieson et al. 1987; Gorecki 1989; Fig. 12.21 here). Mounds and hollows were reported for two open area excavations, MSB and MTG, and these were interpreted to be of similar age and function to the remains of past cultivation reported for Kuk and Mugumamp (see Fig. 12.22 for site MTG).

John Muke directed archaeological investigations on a community coffee plantation at Kana in the middle Wahgi Valley in 1993 and 1994, with additional investigations in 1996 and 1997 (Muke and Mandui 2003). Archaeological investigations were restricted to excavating, recording and sampling within two plantation drains. Two drain sections (WD3 and WD5) were investigated in detail. Several features of possible mid Holocene age were identified, including at least two basins and a ditch (Figs 12.23 and 12.24). The form and function of these features were interpreted to be similar to the basin-like features of similar age at Kuk, Mugumamp and the Manton site at Warrawau.

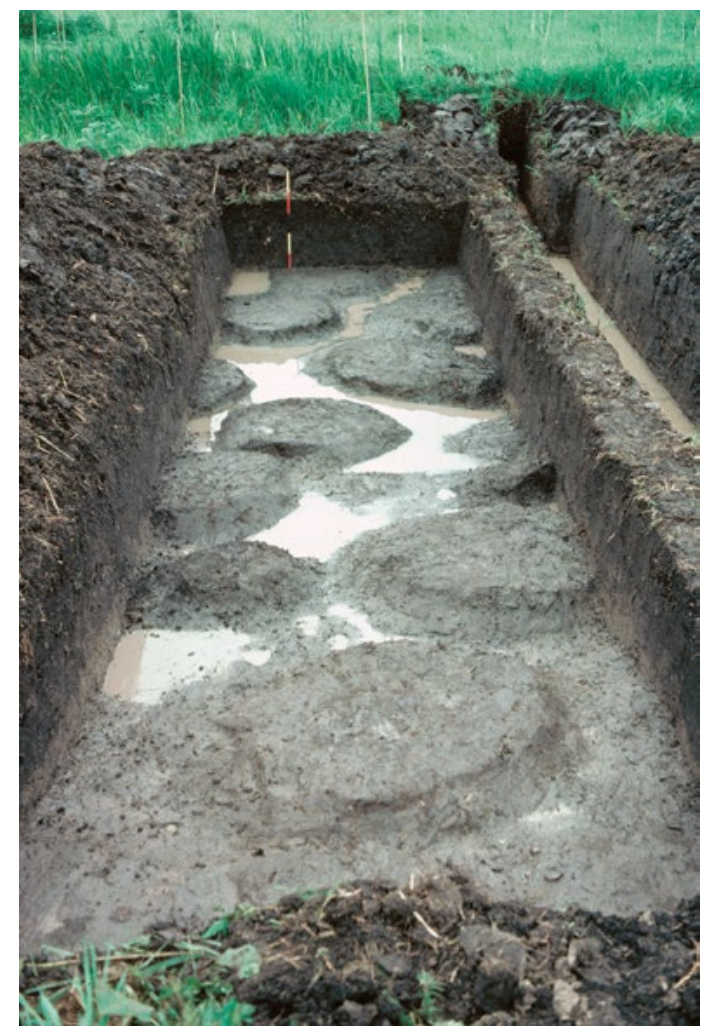

Figure 12.20 Photograph looking SW over the mid Holocene palaeosurface exposed in Trench II at Mugumamp.

Source: Photograph by Ed Harris, Kuk archive 1977.
A recent review of the Ruti and Kana evidence casts doubt on whether these remains represent mid Holocene cultivation (Denham 2003b: 171-172 and 169-170 respectively). Problems arise at both sites in determining the precise age of the remains, how they formed and what they were used for. Until additional archaeological excavations are undertaken, claims of mid Holocene cultivation at both sites should be considered provisional.

Palaeoecological records from other highland valleys show discontinuous and highly variable disturbance of forests using fire from the mid Holocene onwards (Haberle 1994). Palaeoecology suggests that similar landuses to those documented in the upper Wahgi Valley were widespread across the highlands (Powell 1982a: 224), but most of these areas have not been investigated by archaeological excavation to uncover evidence of past cultivation practices. 


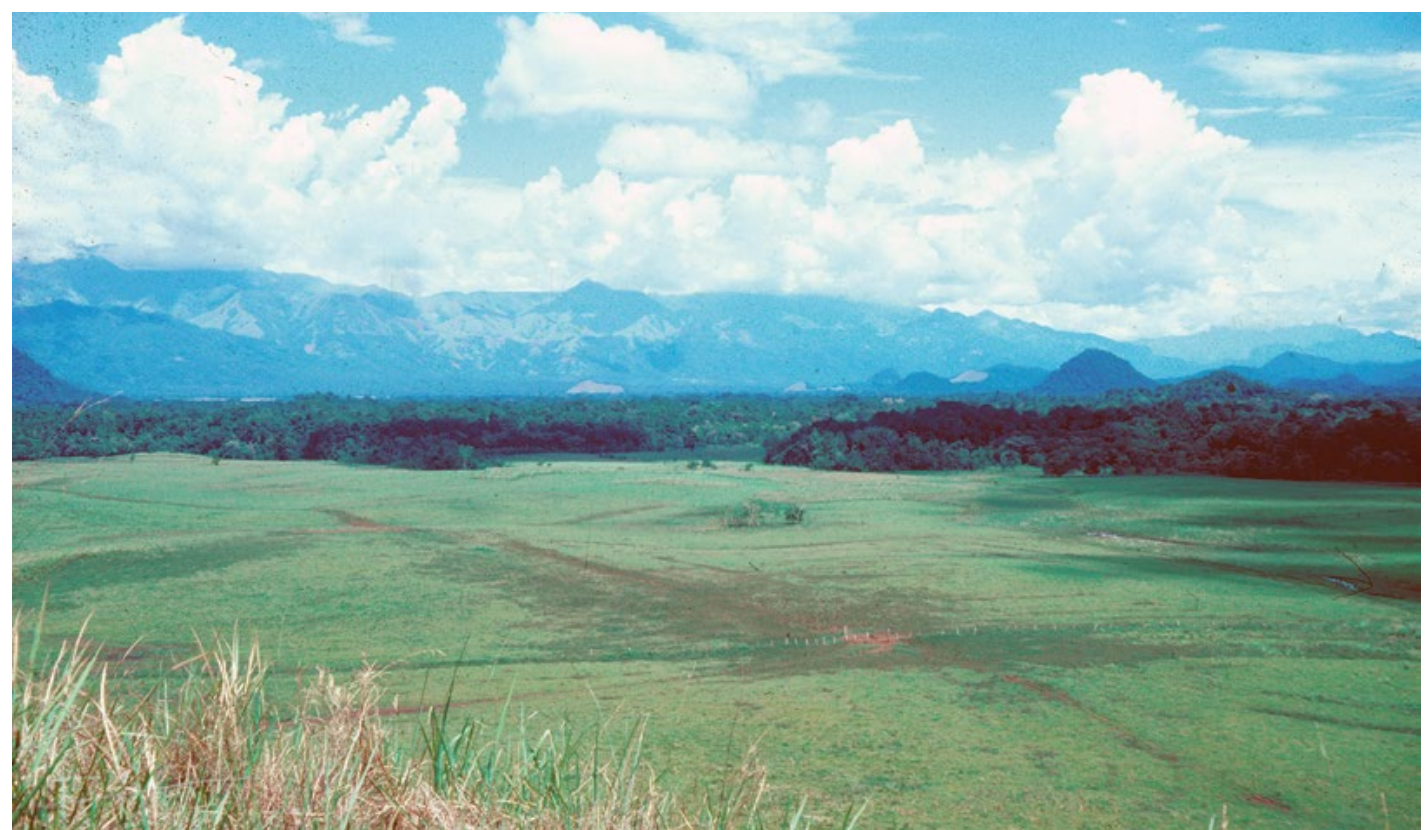

Figure 12.21 Looking NE to the Bismarck Range across Yeni Swamp at the Ruti Flats in the lower Jimi Valley, more than $1000 \mathrm{~m}$ lower in altitude and over $50 \mathrm{~km}$ north of Kuk.

Across the foreground runs a drainage ditch that produced the first artefacts (site MSC), with an excavation thought to contain evidence of gardening (site MSB) some $200 \mathrm{~m}$ away (back and to the left in the image). A second site of suggested gardening, MTG (see Figure 12.22), is nearer the forest edge but off the photograph to the left.

Source: Photograph by Dave Gillieson, 1984, reproduced with permission.
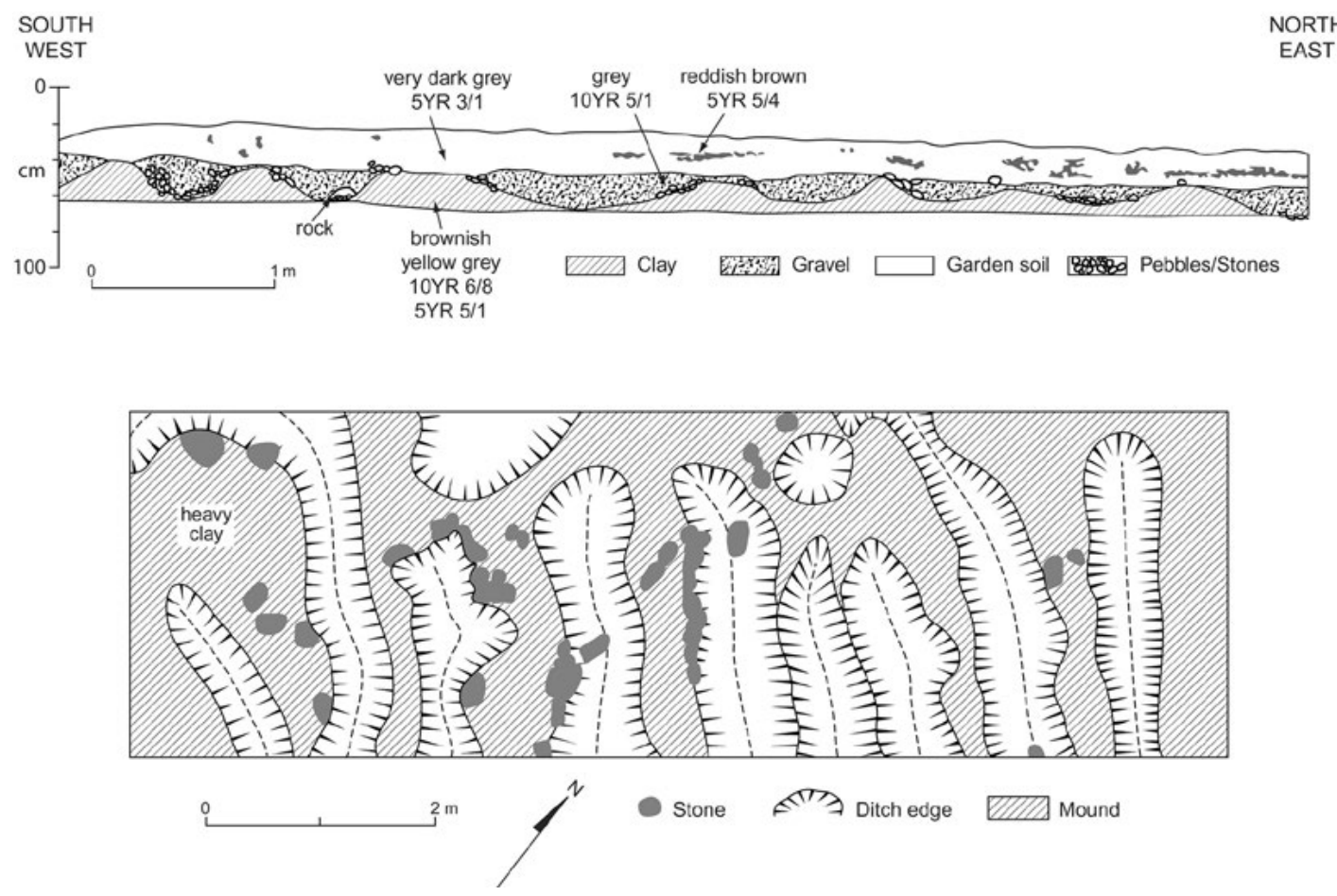

Figure 12.22 Archaeological records of the excavations at site MTG at Yeni Swamp: (upper) NW wall section; and (lower) plan of the base of the trench (note the difference in scales).

Source: Gillieson, Gorecki and Hope (1985: Fig. 5), reproduced with permission. 


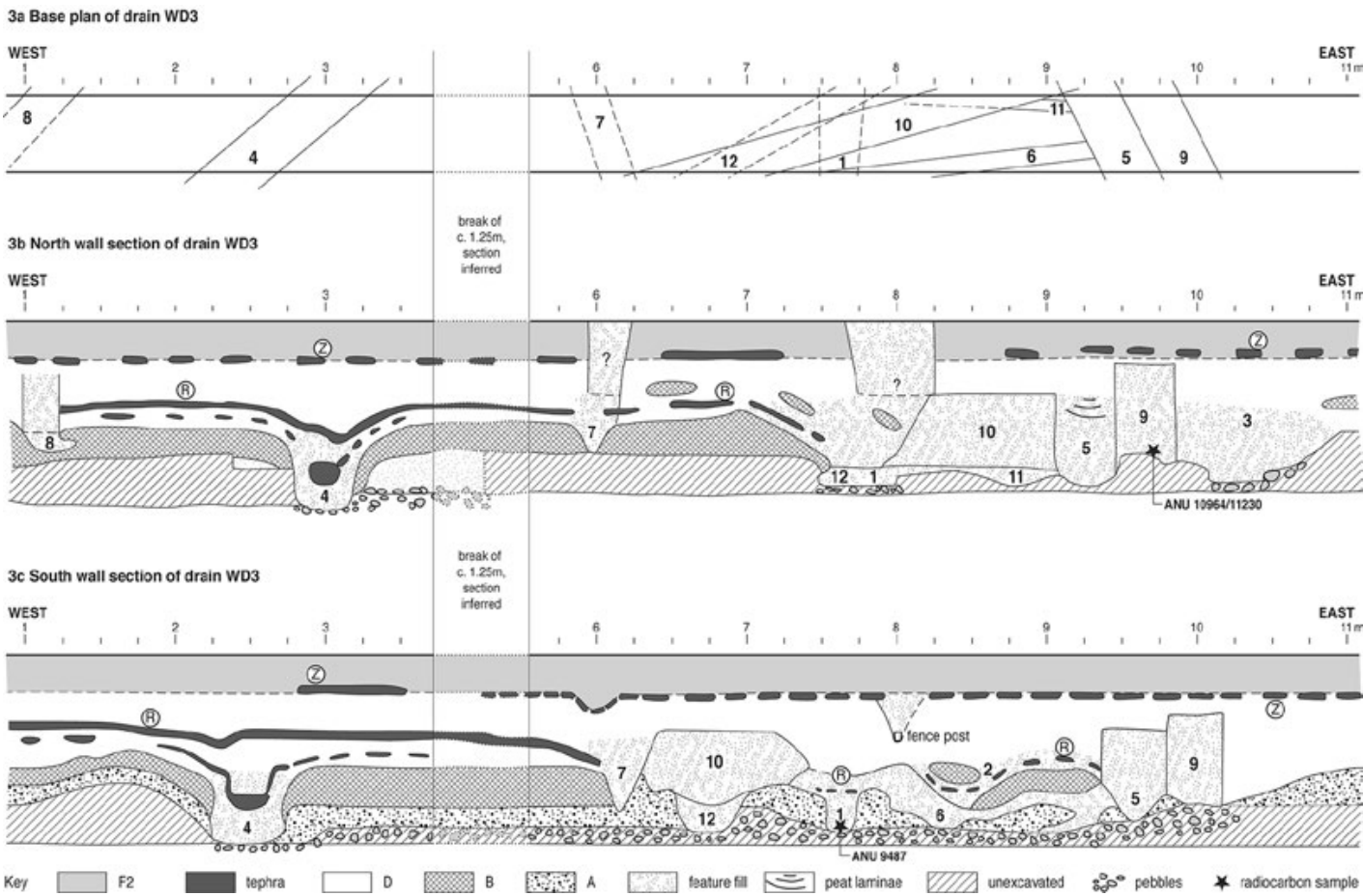

Figure 12.23 Records of excavations in 1994 at drain WD3 at Kana near Minj in the middle Wahgi Valley: (upper) plan of drain base; (middle) section at north wall; and (lower) section at south wall.

Feature 4 was considered by the excavators definitely, and features 2, 3 and 12 possibly, to correlate with Kuk Phase 2 (Muke and Mandui 2003: Table 2). Two additional features of similar suggested age were recorded in drain WD5.

Source: Muke and Mandui (2003: Fig. 3), reproduced with permission.

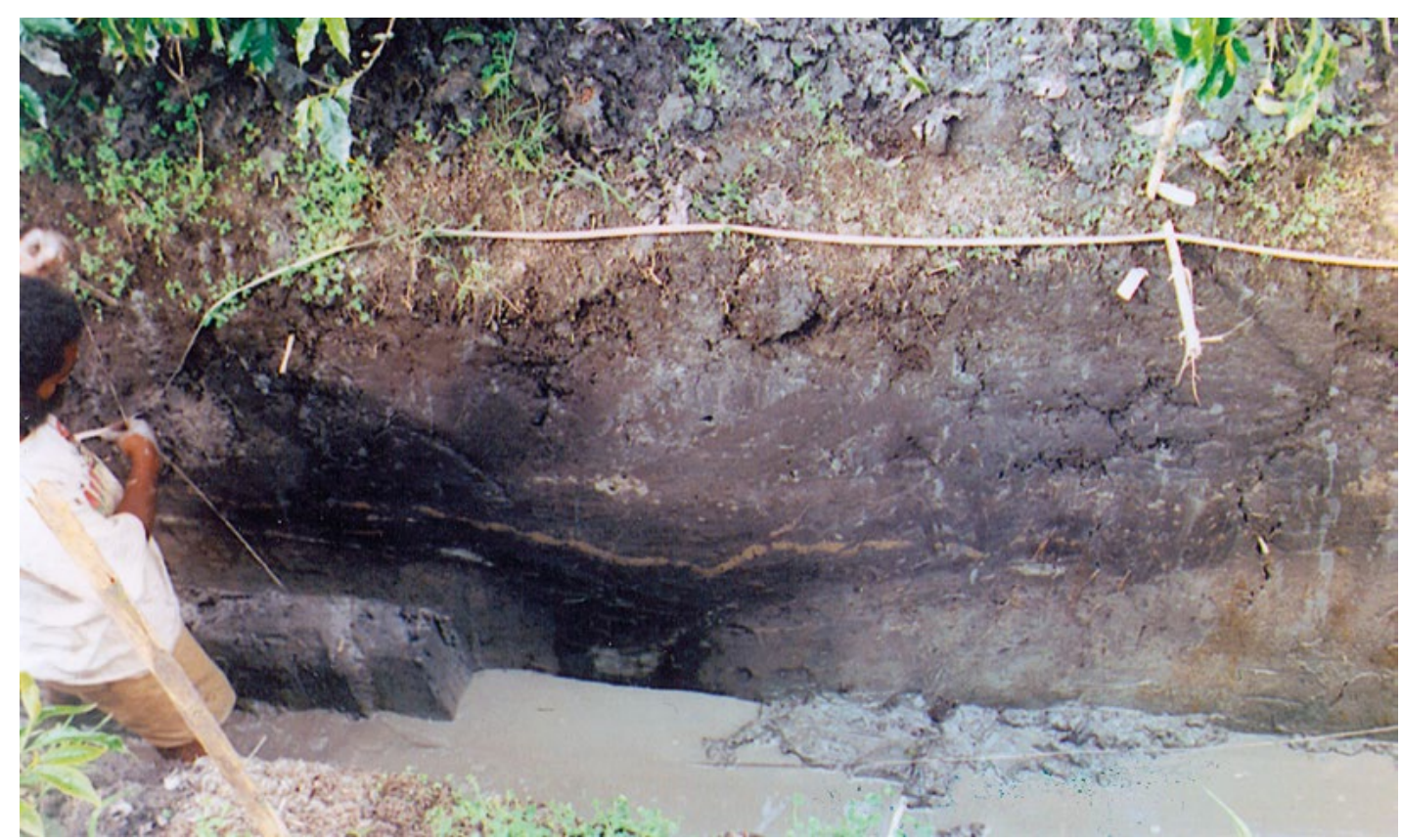

Figure 12.24 Looking at feature 4 at the west end of the north wall of drain WD3 at Kana (see Fig. 12.23 middle).

Feature 4, a ditch with a rounded base, is accepted as being of Kuk Phase 2 age because it is sealed by a continuous stretch of Kim (R) ash dipping over the top of its fill (Muke and Mandui 2003: Table 2).

Source: Photograph by John Muke, 1994. 
This text is taken from Ten Thousand Years of Cultivation at Kuk Swamp in the Highlands of Papua New Guinea, edited by Jack Golson, Tim Denham, Philip Hughes, Pamela Swadling and John Muke, published 2017 by ANU Press, The Australian National University, Canberra, Australia. 